Changes in fluxes of carbon dioxide and methane caused by fire in Siberian boreal forest with continuous permafrost

\title{
Köster, Egle
}

2018-12-15

Köster , E , Köster , K, Berninger , F , Prokushkin , A, Aaltonen , H , Zhou , X \& Pumpanen , J 2018 , ' Changes in fluxes of carbon dioxide and methane caused by fire in Siberian boreal forest with continuous permafrost ' , Journal of Environmental Management, vol. 228 , pp. 405-415 . https://doi.org/10.1016/j.jenvman.2018.09.051

http://hdl.handle.net/10138/310371

https://doi.org/10.1016/j.jenvman.2018.09.051

cc_by_nc_nd

acceptedVersion

Downloaded from Helda, University of Helsinki institutional repository.

This is an electronic reprint of the original article.

This reprint may differ from the original in pagination and typographic detail.

Please cite the original version. 
Environmental Management

Elsevier Editorial System(tm) for Journal of Manuscript Draft

Manuscript Number: JEMA-D-18-02791R2

Title: Changes in fluxes of carbon dioxide and methane caused by fire in Siberian boreal forest with continuous permafrost.

Article Type: VSI:Fire in the Environment

Keywords: Greenhouse gas flux; forest fire; boreal forest; permafrost affected soil; carbon dioxide; methane

Corresponding Author: Dr. Egle Köster, Ph.D.

Corresponding Author's Institution: University of Helsinki

First Author: Egle Köster, Ph.D.

Order of Authors: Egle Köster, Ph.D.; Kajar Köster, PhD; Frank Berninger, PhD; Anatoly Prokushkin, PhD; Heidi Aaltonen, MSc; Xuan Zhou, MSc; Jukka Pumpanen, PhD 


\section{Graphical Abstracts

Graphical abstract

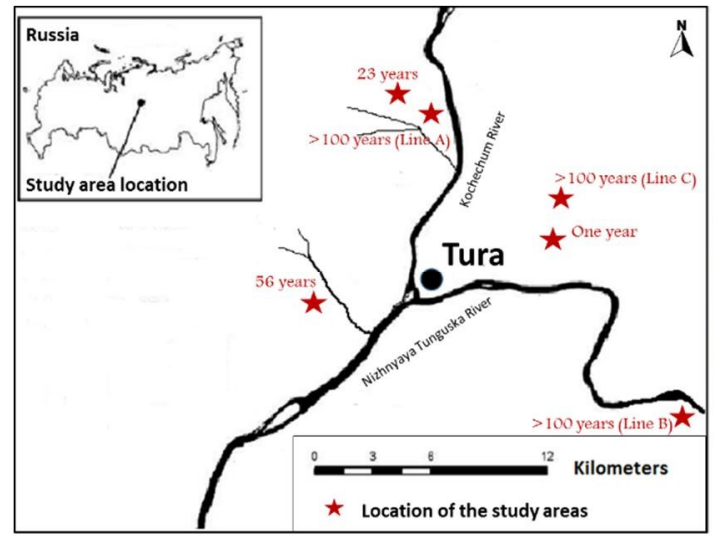

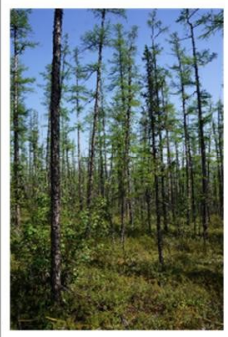

No fire $>$ 100 years

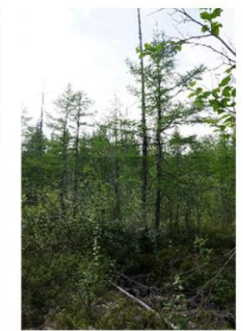

Fire 56 years ago

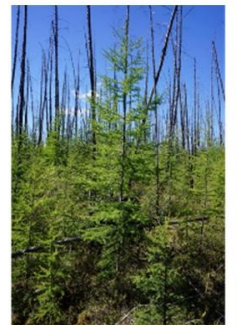

Fire 23 years ago

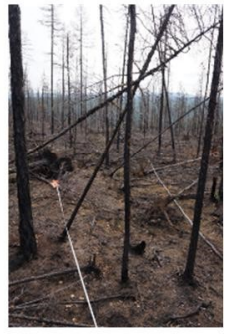

Fire one year ago
Are fire caused changes in $\mathrm{CO}_{2}$ and $\mathrm{CH}_{4}$ fluxes in correlation with the time passed since the last fire?
Does the depth of the active layer on top of the permafrost affect the fluxes of $\mathrm{CO}_{2}$ and $\mathrm{CH}_{4}$ ?
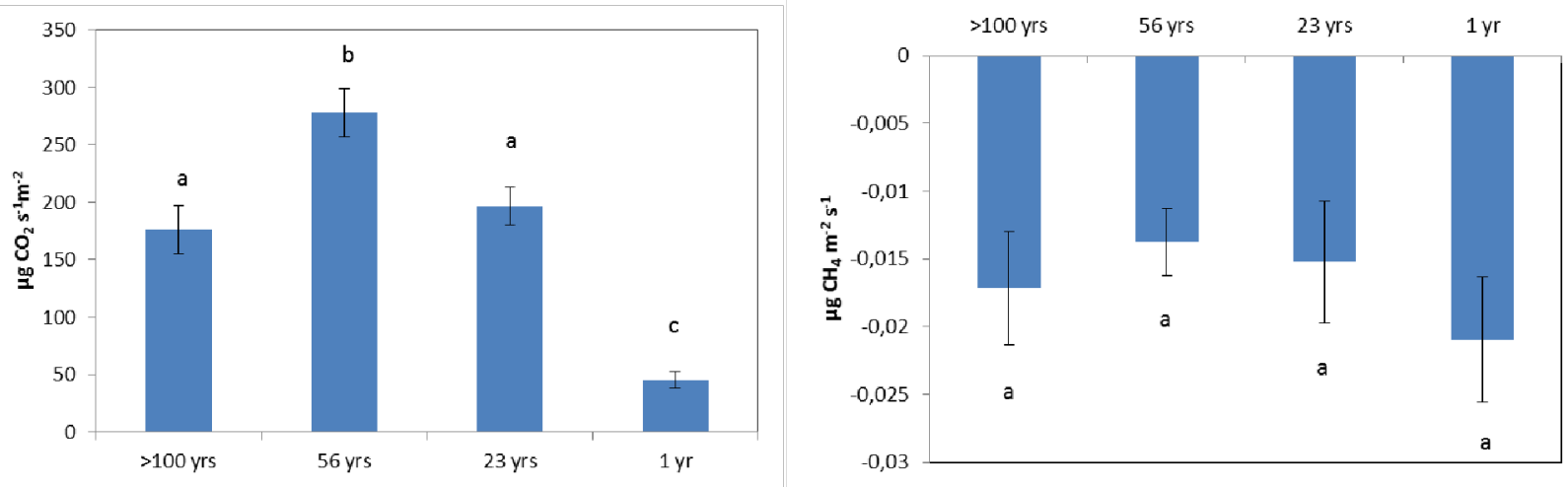

Which characteristics have significant impact on the post-fire change of the $\mathrm{CO}_{2}$ and $\mathrm{CH}_{4}$ fluxes? 
Highlights

- Long-term changes in $\mathrm{CO}_{2}$ and $\mathrm{CH}_{4}$ flux are revealed in the fire chronosequence study.

- $\quad$ Changes in active layer depth influence the emissions of GHG.

- $\quad$ Emissions of $\mathrm{CO}_{2}$ increased with forest age throughout the fire chronosecquence.

- The uptake of $\mathrm{CH}_{4}$ was not influenced by the fire throughout analyzed chronosequence.

- $\quad$ Emissions of $\mathrm{CO}_{2}$ were influenced by the vegetation and soil pH. 
CHANGES IN FLUXES OF CARBON DIOXIDE AND METHANE CAUSED BY FIRE IN SIBERIAN BOREAL FOREST WITH CONTINUOUS PERMAFROST

Egle Köster ${ }^{1,{ }^{*}}$, Kajar Köster ${ }^{1}$, Frank Berninger ${ }^{1}$, Anatoly Prokushkin $^{2}$, Heidi Aaltonen ${ }^{1}$, Xuan Zhou ${ }^{1}$, Jukka Pumpanen ${ }^{3}$

${ }^{1}$ Department of Forest Sciences, University of Helsinki, P.O. Box 27, FI-00014 Helsinki, Finland

${ }^{2}$ V. N. Sukachev Institute of Forest of the Siberian Branch of the Russian Academy of Sciences, the Russian Federation

${ }^{3}$ Department of Environmental and Biological Sciences, University of Eastern Finland, P.O. Box 1627, FI-70211 Kuopio, Finland

${ }^{*}$ Corresponding author:

Egle Köster, PhD

University of Helsinki

Department of Forest Sciences

P.O. Box 27, FI-00014 Helsinki

Tel: +358400258370

e-mail: egle.koster@helsinki.fi 


\section{Abstract}

Rising air temperatures and changes in precipitation patterns in boreal ecosystems are changing the fire occurrence regimes (intervals, severity, intensity, etc.). The main impacts of fires are reported to be changes in soil physical and chemical characteristics, vegetation stress, degradation of permafrost, and increased depth of the active layer. Changes in these characteristics influence the dynamics of carbon dioxide $\left(\mathrm{CO}_{2}\right)$ and methane $\left(\mathrm{CH}_{4}\right)$ fluxes. We have studied the changes in $\mathrm{CO}_{2}$ and $\mathrm{CH}_{4}$ fluxes from the soil in boreal forest areas in central Siberia underlain by continuous permafrost and the possible impacts of the aforementioned environmental factors on the emissions of these greenhouse gases. We have used a fire chronosequence of areas, with the last fire occurring $1,23,56$, and more than 100 years ago. The soils in our study acted as a source of $\mathrm{CO}_{2}$. Emissions of $\mathrm{CO}_{2}$ were lowest at the most recently burned area and increased with forest age throughout the fire chronosequence. The $\mathrm{CO}_{2}$ flux was influenced by the $\mathrm{pH}$ of the top $5 \mathrm{~cm}$ of the soil, the biomass of the birch (Betula) and alder (Duschekia) trees, and by the biomass of vascular plants in the ground vegetation. Soils were found to be a $\mathrm{CH}_{4}$ sink in all our study areas. The uptake of $\mathrm{CH}_{4}$ was highest in the most recently burned area (forest fire one year ago) and the lowest in the area burned 56 years ago, but the difference between fire chronosequence areas was not significant. According to the linear mixed effect model, none of the tested factors explained the $\mathrm{CH}_{4}$ flux. The results confirm that the impact of a forest fire on $\mathrm{CO}_{2}$ flux is longlasting in Siberian boreal forests, continuing for more than 50 years, but the impact of forest fire on $\mathrm{CH}_{4}$ flux is minimal.

Keywords: Greenhouse gas flux; forest fire; boreal forest; permafrost soil; carbon dioxide; methane

\section{INTRODUCTION}

Approximately one third of the world's forest area is covered by boreal forests (Kim and Tanaka, 2003). These forests contain about $66 \%$ of the world's forest soil carbon (C) pools; thus, this biome type has an important role in the global C balance (Kasischke and Stocks, 2000). Russian forests comprise about $70 \%$ of the world's boreal forests and thus their role in the global C cycle cannot be underestimated (Alexeyev et al., 1995; Kasischke and Stocks, 2000). There are more than 520 
million ha of boreal forests in the Russian Federation, containing in total about $119 \mathrm{Pg}$ C, of which about $75 \%$ is stored in soils and forest floor material (Alexeyev et al., 1995; Kasischke and Stocks, 2000).

The boreal forest zone widely overlaps with the area of continuous permafrost (Brown et al., 1997). In the Russian Federation more than $60 \%$ of the terrestrial surface is occupied by permafrost regions (Anisimov and Reneva, 2006). The permafrost in boreal regions is very close to thawing, and the surface organic layer is the most important factor controlling the thickness of the active layer on the permafrost base (Viereck, 1982; Yoshikawa et al., 2003). Generally these high latitude ecosystems are $\mathrm{C}$ sinks, absorbing atmospheric carbon dioxide $\left(\mathrm{CO}_{2}\right)$ through photosynthesis and releasing it slowly from decomposing organic matter (Fan et al., 1998), but even small changes in these large ecosystems may evoke significant changes in the greenhouse gas (GHG) balance of the atmosphere. The occurrence of permafrost makes these ecosystems even more vulnerable to possible disturbances and changing climate (Kim and Tanaka, 2003; Zona, 2016). Increases in the depth of the seasonally thawed active layer may increase soil temperature, and with it decomposition (Grosse et al., 2011). The accompanying decrease in soil moisture is another factor that increases the decomposition rates (Zona, 2016). Increased decomposition in turn leads to elevated $\mathrm{GHG}$ emissions in the form of $\mathrm{CO}_{2}$ and/or methane $\left(\mathrm{CH}_{4}\right)$ (Zona, 2016).

Fire is a critical disturbance in boreal forests, and every year large areas are burned (Kim and Tanaka, 2003; Flannigan et al., 2009). It is estimated that about 5-20 million ha of forests burn annually in the boreal biome (Kasischke and Stocks, 2000; Flannigan et al., 2009, Global Forest Atlas), the majority of which (according to some estimates even about 12 million ha) is in the Russian Federation (Ponomarev et al., 2016). Although human activities are considered to be responsible for about $\mathbf{8 0 - 9 0 \% ~ o f ~ f o r e s t ~ f i r e s ~ i n ~ t h e ~ R u s s i a n ~ F e d e r a t i o n ~ ( K a r p a c h e v s k i y , ~ 2 0 0 4 ) , ~ i n ~}$ remote areas fire occurrence is driven by nature (Ganteaume et al., 2013). In Siberia, larch (Larix sp.) dominates the forest communities, with specific characteristics such as low crown closure and dense ground cover. Although fires in these areas are mostly ground fires, a shallow root zone caused by permafrost is irreversibly damaged in the fire, and so fires in these forests are mostly stand-replacing (Ponomarev et al., 2016). In the areas with a permafrost base, severe wildfires accelerate the degradation of permafrost, and this in turn influences the further succession of the areas (Taş et al., 2014) as well as the C balance of these ecosystems (Kasischke et al., 1995; Takakai et al., 2008). Furthermore, it is suggested that due to climate change the severity of forest 
fires is going to increase by up to $50 \%$ by the middle of the current century (Flannigan et al., 2000). Predicted shorter fire return intervals and increased fire severity leads to younger stands and decreased C storage (Kasischke et al., 1995).

It has been observed that fires strongly influence the soil $\mathrm{C}$ dynamics and thus have an important impact also on GHG fluxes and emission rates (Sullivan et al., 2011; Köster et al., 2017). The release of $\mathrm{CO}_{2}$ and other $\mathrm{GHG}$ into the atmosphere during the combustion process is a primary effect of fire (Nakano, 2006; Urbanski et al., 2009; Sullivan et al., 2011). Fire changes soil physical and chemical properties, respiration and decomposition processes, and soil moisture balance, and these in turn affect the soil GHG fluxes for a long period of time after the fire (Zavala et al., 2014; Köster et al., 2015, 2017). Several studies have referred to the fact that the heat from the fire event does not significantly affect the active layer (Dyrness, 1982; Viereck, 1982; Brown, 1983; Yoshikawa et al., 2003). However, in the permafrost areas the effect of fire is extended, as combustion removes the insulating organic layer and causes a decrease in surface albedo during the summer, allowing the permafrost to thaw (Yoshikawa et al., 2003). Furthermore, due to slow regeneration of vegetation in the boreal permafrost areas, rising soil temperatures may increase the metabolic rates of decomposing microbes in the longer term (Jorgenson et al., 2010). The depth of the active layer has been found to increase for approximately 3-5 years after the forest fire (Dyrness, 1982; Viereck, 1982; Brown, 1983; Yoshikawa et al., 2003) due to decreased soil moisture and increased soil temperatures (Kwon et al., 2016; Zona, 2016). Recovering vegetation allows soils to cool down, and the depth of the active layer starts to reduce (Fisher et al., 2016). Thus, these changes may directly influence the fluxes of $\mathrm{CO}_{2}$ and $\mathrm{CH}_{4}$ between the soil and the atmosphere (Kasischke et al., 1995; Kim and Tanaka, 2003; Kim, 2013).

$\mathrm{CO}_{2}$ emissions from the soil originate from the decomposition of soil organic matter and plant root respiration, and are the major component of the global terrestrial C cycle (Takakai et al., 2008). Forest fires directly influence ecosystem $\mathrm{C}$ dynamics and $\mathrm{CO}_{2}$ flux. During the fire, a pulse of $\mathrm{CO}_{2}$ and $\mathrm{CH}_{4}$ from the combustion process is released into the atmosphere (Nakano, 2006; Sullivan et al., 2011; Taş et al., 2014). However, post-fire soils have the potential to release more $\mathrm{CO}_{2}$ and $\mathrm{CH}_{4}$ to the atmosphere due to changed soil moisture conditions and elevated temperatures (Ullah and Moore, 2011). It has been observed that after the fire, the decomposition of fire-produced necromass releases about three times more $\mathrm{CO}_{2}$ from the soil (Burke et al., 1997). In permafrost areas, the degradation of permafrost and deepening of the active layer promotes the release of $C$ 
stored in the frozen soil (Zona, 2016), which elevates further the impact of fire on the chemical composition of the atmosphere and the Earth's climate system (Urbanski et al., 2009).

Non-paludified boreal forests usually act as sinks of $\mathrm{CH}_{4}$ (Kulmala et al., 2014; Köster et al., 2015). It has been observed that in boreal forests, fire increases the uptake of $\mathrm{CH}_{4}$ (Takakai et al., 2008; Kulmala et al., 2014; Taş et al., 2014; Morishita et al., 2015), and site-specific environmental conditions (soil hydrology, vegetation, soil biota, available soil organic $\mathrm{C}$ etc.) are the main drivers of the post-fire changes in $\mathrm{CH}_{4}$ fluxes (Nakano, 2006; Sullivan et al., 2011). In southern boreal forests, the uptake of $\mathrm{CH}_{4}$ increases after the fire, returning to initial unburned conditions after one year (Kulmala et al., 2014; Taş et al., 2014). It is suggested that the main reason for this is the fast recovery of the microbial community (Kulmala et al., 2014). In northern boreal forest with a permafrost base, the influence of fire on the $\mathrm{CH}_{4}$ flux should last longer, as the post-fire induced thawing of the permafrost influences the soil temperatures and soil hydrological conditions for a relatively long period of time (Yoshikawa et al., 2003; Zona, 2016).

Although the effect of fire on permafrost forest areas has evoked the interest of scientists for a long time, the long-term (decadal) changes in the fluxes of different GHGs caused by forest fires have received less attention as most studies concentrate on the short-term (time scale of a few years) changes (Takakai et al., 2008; Morishita et al., 2015; Song et al., 2018). In this study, we investigated a long-term chronosequence of forest fires in boreal deciduous coniferous forests with a permafrost base in the central part of Siberia, the Russian Federation. Areas that had differing time periods since the last forest fire, but with comparable ecological conditions, were chosen for testing the long-term impact of fire on $\mathrm{CO}_{2}$ and $\mathrm{CH}_{4}$ fluxes. We compared the role of factors such as time since fire, soil temperature, soil moisture, depth of the active layer, living and dead tree biomass, and ground vegetation biomass (grasses and mosses), and estimated how these factors influence the GHG fluxes across a fire chronosequence. Our key research question was: How does time since the last forest fire influence the soil $\mathrm{CO}_{2}$ and $\mathrm{CH}_{4}$ fluxes in permafrost areas? Our hypotheses were: a) the fluxes of $\mathrm{CO}_{2}$ and $\mathrm{CH}_{4}$ will change as a consequence of fire and associated permafrost thawing, and the magnitude of the changes correlates with the time since the last fire; b) the fluxes of $\mathrm{CO}_{2}$ and $\mathrm{CH}_{4}$ are positively correlated with the depth of the active layer on top of the permafrost during the vegetation period; and c) the recovery of the $\mathrm{CO}_{2}$ and $\mathrm{CH}_{4}$ fluxes to the pre-fire levels is related to the recovery of the vegetation. 


\section{METHODS}

\subsection{Study area}

An intensive measurement campaign was conducted in July 2016, close to Tura (Evenkiysky district of Krasnoyarsk kray, the Russian Federation) $\left(64^{\circ} 16^{\prime} \mathrm{N}, 100^{\circ} 13^{\prime} \mathrm{E}\right)$ in the northern part of the Central Siberian Plateau. The study sites are located within the basin of the Nizhnyaya Tunguska River and its tributary, the Kochechum River, both belonging to the Yenisei River watershed (Fig. 1).

The study area has continuous permafrost (Osawa and Zyryanova, 2010) and a cold continental climate. The average temperature in January (the coldest month) is $-36^{\circ} \mathrm{C}$, and in July (the warmest month) $16^{\circ} \mathrm{C}$ (Prokushkin et al., 2006). The average annual temperature is $-9.5^{\circ} \mathrm{C}$ (Startsev et al., 2017). Average annual precipitation for the region is $250-390 \mathrm{~mm}$ (Prokushkin et al., 2006; Kharuk et al., 2011), about $30-40 \%$ of which falls as snow, which commonly covers the ground for about 219-235 days a year (Prokushkin et al., 2006). Average summer precipitation is about $180 \mathrm{~mm}$ (Kharuk et al., 2011).

Soils of the area are characterized by a large proportion of gravel, shallow $(20-40 \mathrm{~cm})$ depths, and low or medium clay contents of fine earth (Prokushkin et al., 2006). Based on the soil geographic division of the Russian Federation, soils in the area belong to the central Siberian province of permafrost-affected taiga soils, with a predominance of cryozems with shallow permafrost (Startsev et al., 2017). According to the IUSS Working Group, the soils in the area are classified as gelisols (IUSS Working Group WRB, 2006). Soils of the area have slightly acidic pH.

Vegetation in the area is dominated by larch (Larix gmelinii (Rupr.) Rupr.) trees, with rare birch (Betula pubescens Ehrh.), spruce (Picea obovata Ledeb.), and shrub alder (Duschekia fruticosa (Rupr.) Pouzar. Ground vegetation consists of ericoid dwarf shrubs (mainly Ledum palustre L., Vaccinium vitis-idaea L., and Vaccinium uliginosum L.), mosses (Pleurozium schreberi (Brid.) and Aulacomnium palustre (Hedw.) Schwaegr.), and patches of lichens (Cladina spp. and Cetraria spp.).

\subsection{Study design}

In the summer of 2016, four different study areas were established, each with a different time since the last stand-replacing forest fire (age class): last forest fire in 2015 (one year), 1993 (23 
years), 1960 (56 years), and no fires for at least 100 years (the last forest fire in that area was in 1899) (S. 1). The selection of areas was based on the average fire return interval, which is considered to be about $82 \pm 7$ years in these areas (Kharuk et al., 2011). We also took into consideration earlier studies, which reported that the time for permafrost to reach the pre-fire depth is between 60 and 100 years (Viereck, 1982; Kasischke et al., 1995; Jorgenson et al., 2010). A hierarchical sampling procedure was adopted. At each age class area we established three lines of $150 \mathrm{~m}$ length with three sample plots along each line at $50 \mathrm{~m}$ intervals. The lines were spaced at least a few hundred meters from each other, and were set at least $150 \mathrm{~m}$ from the nearest road to avoid disturbance of the snow cover and consequently the permafrost stability of the area. The lines were spaced in such a way that the effect of slope was minimal and soil conditions were similar. Thus the lines were placed in as flat terrain as possible to minimize the effect of the topographic variation.

We had nine sample plots $\left(400 \mathrm{~m}^{2}\right)$ per age class and measurements of stand characteristics were made on all of them. Ground vegetation cover, biomass, species composition, and living and dead tree biomass were measured. Ground vegetation biomass was measured in four $0.20 \times 0.20 \mathrm{~m}$ squares per sample plot. Specific composition and coverage of each species was estimated visually from the entire sample plot, and the coverage of vascular plants, lichens, and mosses was estimated in $0.75 \times 0.75 \mathrm{~m}$ squares. Characteristics of all trees (minimum of $1 \mathrm{~m}$ height) inside the sample plots were measured (stem diameter at $1.3 \mathrm{~m}$ height or on the ground for smaller trees, tree height, crown height, and crown diameter). For the larch trees, we used the allometric equation provided in Larjavaara et al. (2017) for the tree biomass calculations. For birch, the equations from Repola (2008) were used. For alder biomass calculations we developed a new allometric equation based on the destructive sampling of alder trees. A non-linear model was fitted relating aboveground biomass $(A G B)$ to tree diameter $(d b h, \mathrm{~mm})$ :

$A G B=1.838 * d b h^{2.0396}$

One soil pit was excavated in the middle of each sample plot, with altogether 36 soil pits. Soil samples (for soil $\mathrm{C}$ ) and nitrogen $(\mathrm{N})$ concentration, $\mathrm{pH}$, and texture analyses) were taken from the litter and humus layer, and if possible, from the mineral soil at $0.05 \mathrm{~m}, 0.30 \mathrm{~m}$, and $0.50 \mathrm{~m}$ depths and as close to the permafrost as possible. We used a steel cylinder $(0.06 \mathrm{~m}$ diameter, $0.06 \mathrm{~m}$ length) for collection of the soil samples from the vertical surface of the soil pit from three different walls of the pit. The depth of the active layer above the permafrost was also measured. 
When the permafrost could not be reached, the depth of the active layer was calculated using a linear extrapolation of the soil temperature profile (measurements at $0.02 \mathrm{~m}, 0.05 \mathrm{~m}$, and $0.1 \mathrm{~m}$ depths) for the mineral soil.

The soil samples used for soil $\mathrm{C}$ and $\mathrm{N}$ concentration and $\mathrm{pH}$ measurements were stored at a cold temperature $\left(4^{\circ} \mathrm{C}\right)$ until analysis. Prior to analysis, roots and stones were separated from the mineral soil by sieving through a $2 \mathrm{~mm}$ sieve. Soil pH was analyzed from a soil extract with a glass electrode (Standard pH meter, Radiometer Analytical, Lyon, France) in $35 \mathrm{~mL}$ soil suspensions consisting of $10 \mathrm{~mL}$ of soil sample and $25 \mathrm{~mL}$ of ultrapure Milli-Q water (left to stand overnight after mixing). Soil dry weight was measured from the homogenized soil samples by drying at $105^{\circ} \mathrm{C}$ until constant weight. The dried samples were further homogenized by grinding with a mortar grinder (Retsch, type RMO, Bioblock Scientific, Haan, Germany) and the $\mathrm{C}$ and $\mathrm{N}$ concentrations were measured using an elemental analyzer (varioMAX CN elemental analyzer, Elementar Analysensysteme $\mathrm{GmbH}$, Germany), operated in $\mathrm{C} / \mathrm{N}$ mode. Based on the measurements, soil $\mathrm{C}$ and $\mathrm{N}$ stocks were calculated.

\subsection{Chamber measurements of carbon dioxide and methane}

The static chamber method was employed for measurements of $\mathrm{CO}_{2}$ and $\mathrm{CH}_{4}$ fluxes between the soil and the atmosphere (Pihlatie et al., 2013). Gas flux measurements were made during the summer of 2016 (July, 3 to 17) on metal collars (18 collars per fire age class with diameter $0.21 \mathrm{~m}$ and height $0.05 \mathrm{~m}$ ) installed in the soil before measurements. The lower edge of the collar was placed at $0.02 \mathrm{~m}$ depth in the mor layer above the rooting zone to avoid damaging the roots, and it was sealed with sand to prevent the leakage of air below the collar. The vegetation inside the chamber was not damaged, and it remained in the collar during the measurements.

Soil temperature was measured close to each chamber during the flux measurements in the field from $0.02 \mathrm{~m}, 0.05 \mathrm{~m}$, and $0.1 \mathrm{~m}$ depth with a digital thermometer ( $\mathrm{P} 300 \mathrm{w}$ temperature probe, Dostmann Electronic GmbH, Germany). Simultaneously, soil water content measurements were made with soil moisture sensors at $0.05 \mathrm{~m}$ depth (ThetaProbe ML3, Delta-T Devices Ltd, Cambridge, UK) connected to a data reader ( $\mathrm{HH} 2$ moisture meter, Delta-T Devices Ltd, Cambridge, UK). There were no strong fluctuations in weather conditions during the measurement period (comparable air temperatures and precipitation). 
All chamber measurements were carried out during the daytime. A cylindrical chamber $(\mathrm{h}=0.24 \mathrm{~m}$ and $\varnothing=0.20 \mathrm{~m}$ ) covered with aluminum foil (to prevent photosynthesis) was used in the flux measurements. Circulation of air inside the chamber was achieved with a small fan $(0.025 \mathrm{~m}$ in diameter). For the air sampling, the chamber was equipped with an outlet tube that could be closed and opened with a three-way valve (BD Connecta TM Stopcock, Becton Dickinson, NJ, USA). The $\mathrm{CO}_{2}$ and $\mathrm{CH}_{4}$ gas samples were collected from the chamber headspace by connecting a $50 \mathrm{~mL}$ polypropylene syringe (BD Plastipak 60, BOC Ohmeda, Helsingborg, Sweden) equipped with a similar three-way valve to the outlet tube of the chamber. Air samples were collected before the chamber was placed on the collar ( 0 minutes) and 1, 3, 5, 10, and 20 minutes after, and they were injected immediately into glass vials (12 mL Soda glass Labco Exetainer ${ }^{\circledR}$, Labco Limited, UK) for storage and transportation. The samples were analyzed using a gas chromatograph (Agilent 6890 N, Agilent Technologies Inc., USA).

Samples were analyzed using a six-point standard curve (Pihlatie et al., 2013). Linear regression fitted to time and concentration change inside the chamber headspace was employed for calculations of $\mathrm{CO}_{2}$ and $\mathrm{CH}_{4}$ fluxes. The filtering of the outliers from the measured $\mathrm{CO}_{2}$ and $\mathrm{CH}_{4}$ concentrations was based on the deviation of individual data points from the slope of the linear regression line and the standard deviation of the data points (Iglewicz and Hoaglin, 1993).

\subsection{Data analysis}

Data were checked for normality using the Shapiro-Wilk test.

The Pearson correlation coefficient $(\rho)$ was calculated to estimate the linear correlation between analyzed variables $(-1<\rho<1)$. The statistical significance $(p)$ for the $\rho$ was estimated as the probability of $\rho<0.05$ under $\mathrm{H}_{0}: \rho=0$, and the number of observations was $\mathrm{n}=71$.

A linear mixed model was employed to analyze the significance of time passed from the last forest fire $(Y r)$, and to explain the variation in fluxes of both measured GHGs. The collars in each sample line $(B)$ were treated as a random effect and $\varepsilon$ represented residuals.

$G H G=a+b Y r+\beta+\varepsilon$ 
Collinearity between all measured experimental variables was tested using variance inflation factors (VIFs) (James et al., 2000), which removed the collinear variables until the VIF was lower than 2.0. Those selected variables were included in the initial model. Then a linear mixed effect model was used to explain how experimental factors affected the GHG fluxes. Soil moisture (SM), soil $\mathrm{pH}$ in the top $5 \mathrm{~cm}\left(\mathrm{pH}_{0}\right)$, soil $\mathrm{pH}$ from the mineral part of the soil $\left(p H_{M}\right)$, tree biomass of alder $(T B(D))$, tree biomass of birch $(T B(B))$, tree biomass of larch $(T B(L))$, biomass of vascular plants $(B(G))$, biomass of mosses and lichens $(B($ Moss $))$, and soil $C$ stocks $\left(\mathrm{kg} \mathrm{m}^{-2}\right)(C)$ were included as fixed effects in the initial model, whereas the collars in each sample line $(B)$ were treated as a random effect and $\varepsilon$ represented residuals. We selected the best model using stepwise selection. Model selection was based on the Akaike information criterion (AIC) (Akaike, 1998). This was done using the drop1 function (Chambers, 1992) in R (“Ime4" package (Bates et al., 2015)).

The initial model included:

$G H G$ flux $=a+b S M+c p H 0+d p H M+e T B(D)+f T B(B)+g T B(L)+h B(G)+i B(M)+$ $j C+r(Y L)+\beta+\varepsilon$

where GHG flux is the greenhouse gas flux $\left(\mathrm{CO}_{2}\right.$ and $\mathrm{CH}_{4}$ were done separately), $a$ is the intercept of the model, $b, c, d, e, f, g, h, l$, and $j$ are the slopes of the variables, and $\varepsilon$ represents the residuals. The best model had the lowest AIC and highest pseudo $r^{2}$ value. For each gas model, the normality model residuals were visually checked using a quantile-quantile plot ( $Q-Q$ plot) (Faraway, 2002) method in R (RStudio, version 1.0.136, RStudio, Inc.). The linear mixed effect model analyses were carried out with R using the "Ime4" package (Bates et al., 2015).

A Tukey's honest significant difference post hoc-test was used for comparison of age class effects for all measured GHG fluxes ( $p<0.05$ was considered a significant difference).

\section{RESULTS}

3.1. Fire impact on the soil properties and vegetation

Daily average air temperature in the area during the measurement period was $18.8^{\circ} \mathrm{C}$ (ranging from $17^{\circ} \mathrm{C}$ to $21^{\circ} \mathrm{C}$ ), and precipitation during the same period was $8.5 \mathrm{~mm}$. 
The average depth of the active layer varied significantly between the areas, and there was a negative correlation between the age since the last fire and the depth of the active layer $(\rho=$ $-0.712, p<0.0001$ ) (Table 1). A clear trend of permafrost recovery was observed, as the depth of the active layer decreased with time since the last fire. In the area burned most recently, the average depth of the active layer was $1.31 \mathrm{~m}$ (ranging from $1.15 \mathrm{~m}$ to $1.58 \mathrm{~m}$ ). In the area burned 23 years ago, the active layer depth had already decreased to $0.77 \mathrm{~m}$, and in the area burned 56 years ago, the active layer depth was $0.53 \mathrm{~m}$ (Table 1 ). Soil organic layer thickness correlated positively with time since the last fire $(\rho=0.820, p<0.0001)$ (S. 2). During the fire the thickness of the soil organic layer had decreased significantly, being $0.005 \mathrm{~m}$ at the area burned one year ago, while in all the other studied areas it was more than $0.075 \mathrm{~m}$ (Table 1).

The average soil moisture content at $0.05 \mathrm{~m}$ depth at the study sites ranged from $40.1 \%$ to $23.6 \%$, being the lowest at the most recently burned site and highest in the area burned > 100 years ago(Table 1). There was a positive correlation between soil moisture and the time elapsed since the forest fire $(\rho=0.383, p=0.0021)$ (S. 2). Soil temperatures measured at $10 \mathrm{~cm}$ depth correlated negatively with the time of the last forest fire $(\rho=-0.773, p<0.0001)$ (S. 2$)$. The lowest soil temperatures were measured in the area burned $>100$ years ago (average $=3.3^{\circ} \mathrm{C}$ ) and the highest in the most recently burned area (average $=14.9^{\circ} \mathrm{C}$ ) $($ Table 1$)$. The $\mathrm{pH}$ of the top $5 \mathrm{~cm}$ of the soil consisting mostly of organic matter averaged between 5.1 and 5.8, and no correlation with time since the last fire was detected ( $p=0.0854$ ) (Table 1, S. 2). However, the pH correlated with several factors such as soil temperature and $\mathrm{CO}_{2}$ fluxes for example (S. 2). The $\mathrm{pH}$ of the mineral soil layer was slightly higher, ranging from 6.1 to 6.5 , being slightly lower at the area burned 56 years ago when compared with the other fire age classes. There was no correlation between the time of the fire and the $\mathrm{pH}$ of the mineral soil $(p<0.4652)(\mathrm{S} .2)$.

The total C pool of the soil was significantly lower in the most recently (one year ago) burned area compared with the others, and there was a positive linear correlation between the time of the fire and the soil C stocks ( $\rho=0.428, p=0.0005$ ) (Table 1, S. 2). The amount of $C$ in the soil organic layer was strongly affected by the fire: in the most recently burned area the $\mathrm{C}$ stock of the organic layer was significantly lower (average $=0.26 \mathrm{~kg} \mathrm{~m}^{-2}$ ) than in the other sites (average $>2.67 \mathrm{~kg} \mathrm{~m}^{-2}$ ) (Table 2). Also, the $\mathrm{C}$ pool in the soil mineral layer was affected by the fire: at the most recently burned site the $C$ stock of the mineral layer was lower than in the other sites (average $=2.71 \mathrm{~kg}$ $\mathrm{m}^{-2}$ ) (Table 2). The soil $\mathrm{N}$ stocks were highest in the area which had burned more than 100 years 
ago and lowest in the area burned one year ago, and soil $\mathrm{N}$ stocks correlated positively with the time since the last fire $(\rho=0.416, p=0.0008$ ) (Table 1$)$. The $N$ stocks of the soil organic layer decreased significantly due to the fire and combustion of the organic layer, being about $0.01 \mathrm{~kg} \mathrm{~m}^{-2}$ one year after the fire. Over time, the $\mathrm{N}$ stocks increased, reaching about $0.19 \mathrm{~kg} \mathrm{~m}^{-2}$ in the area burned $>100$ years ago (Table 2). The $\mathrm{N}$ stocks of the soil mineral layer were less affected by the fire (Table 2 ).

Time passed since the last forest fire had a significant effect on the ground vegetation of the study areas. In the area burned in 2015 (one year ago), there was no vegetation present. For vascular plants only a few specimens of grasses could be found and rare patches of Marchantia moss were present. Although there was a full coverage of ground vegetation in the three oldest areas, the balance between different vegetation groups in these areas was different. All these areas were characterized by moss cover (Pleurozium schreberi and Hylocomium splendens), with some patches of Cladina spp. lichens. In addition to those, patches of Dicranum spp. and Rhytidiadelphus spp. were also present in some plots. The most dominant species of dwarf shrub layer were Rhododendron tomentosum Harmaja, Vaccinium uliginosum L., and V. vitis-idaea L. The coverage of mosses and lichens was highest in the oldest study area (> 100 years) and lowest in the most recently burned area, while the coverage of vascular plants was highest 23 years after fire and reduced with time since the fire (Table 1). Both the biomass of mosses and lichens and the biomass of vascular plants were positively correlated with the time passed since the fire (respectively, $\rho=0.610, p<0.0001$, and $\rho=0.343, p=0.0063$ ) (Table 1, S. 2).

The different tree species had different response to time since the last fire in our study areas. There was a clearly positive correlation between the time since the last fire and the biomass of both the larch and alder trees (S. 2). The biomass of the birch trees was not affected by the time since the last fire (Table 1). The biomass of birch and alder trees was at its highest level in the area burned 56 years ago, while the biomass of larch trees reached its maximum in the area burned more than 100 years ago (Table 1 ).

\subsection{Fire impact on the flux of carbon dioxide from the soil}

The $\mathrm{CO}_{2}$ emissions increased throughout the time since the fire, and there was a significant positive correlation between the $\mathrm{CO}_{2}$ emissions and the time since the last forest fire $(\rho=0.408, p$ 
$=0.0010)$. The highest $\mathrm{CO}_{2}$ efflux was measured in the area that had burned 56 years ago. The most recently burned area (one year ago) could be distinguished from all the others by having the lowest $\mathrm{CO}_{2}$ emissions (Fig. 2).

To avoid the collinearity with other factors, the time since the last fire was tested separately. It explained $13 \%$ of the variation in $\mathrm{CO}_{2}$ emissions $(p=0.11)$. Based on these results, we tested other factors. To obtain the best model the factors with the lowest contribution (lowest AIC value) were removed from the original model. According to the linear mixed model, the flux of $\mathrm{CO}_{2}$ was not significantly affected by soil moisture, $\mathrm{pH}$ of the mineral soil, the biomass of the larch trees and mosses, and by the total $\mathrm{C}$ content of the soil. The best model (Model 6) for explaining the $\mathrm{CO}_{2}$ flux (Table 3) indicated that the $\mathrm{CO}_{2}$ flux was influenced by the $\mathrm{pH}$ of the top $5 \mathrm{~cm}$ of the soil containing mostly organic matter, the biomass of the alder and birch trees, and the biomass of vascular plants in ground vegetation (S. 3). This model explained $62 \%$ of the variation in $\mathrm{CO}_{2}$ flux ( $p$ $=0.004)$ (Table 3). All factors from the best model were highly correlated with the $\mathrm{CO}_{2}$ emissions (Table 3, Model 6, S. 3).

\subsection{Fire impact on the flux of methane}

Soil was a $\mathrm{CH}_{4}$ sink in all the areas in our study. The average uptake of $\mathrm{CH}_{4}$ was highest in the most recently burned area, and lowest in the area burned 56 years ago, but the differences were not statistically significant (Fig. 3). The $\mathrm{CH}_{4}$ flux had no linear correlation with any of the measured experimental factors (Table 1, S. 2) nor with the time since the last fire $(\rho=0.049, p=0.7049)$.

We tested the effect of the time since the last forest fire on the $\mathrm{CH}_{4}$ flux with the linear mixed model. Results revealed that the time since the last fire explained only $0.6 \%$ of the variation in $\mathrm{CH}_{4}$ flux, and the effect was non-significant $(p=0.64)$. Based on the results, other factors were analyzed. Low contributing factors such as the soil moisture, $\mathrm{pH}$ of the top $5 \mathrm{~cm}$ of soil, biomass of different tree species and mosses, the thickness of the soil organic layer, and the $\mathrm{C}$ content of the soil were removed from the original model to obtain the best model (Table 4, Model 8). The best model to explain the $\mathrm{CH}_{4}$ flux indicated that the $\mathrm{CH}_{4}$ flux was mostly influenced by the $\mathrm{pH}$ of the soil mineral layer and the ground vegetation biomass of the vascular plants. However, this model explained only $23 \%$ of the variation in $\mathrm{CH}_{4}$ flux, and as a whole, the model was not statistically significant $(p=0.22)$ (Table 4, S. 4). 


\section{DISCUSSION}

Our study of fire chronosequence showed that fire significantly decreased the $\mathrm{CO}_{2}$ emissions while it had no significant effect on the $\mathrm{CH}_{4}$ uptake. In time, the $\mathrm{CO}_{2}$ efflux increased, but the $\mathrm{CH}_{4}$ flux did not change throughout the studied chronosequence. Biological processes were more important compared with soil temperature, which is generally found to affect fluxes of these GHGs (Oertel et al., 2016).

\subsection{Fire impact on the soil properties and vegetation}

The study areas have suffered severe and intensive stand-replacing fire disturbances. Our results showed that the depth of the active soil layer was substantially affected by fire - one year after the fire the depth of the active layer had increased significantly (Table 1). We also observed the highest soil temperatures in the most recently (one year ago) burned area (Table 1). The initial reason for the post-fire increase in soil temperature is the missing vegetation and moss cover (Viereck, 1982) and combustion of the soil organic layer (Dyrness, 1982; Burke et al., 1997). Postfire darker ground and changes in its reflectance (Pereira et al., 2013; Zavala et al., 2014) result in an increase in soil temperature and thawing of the underlying permafrost (Yoshikawa et al., 2003; Pereira et al., 2013; Zavala et al., 2014). A number of studies have been published on the effects of fire on the thermal regime of the ground (Liang et al., 1991; Yoshikawa et al., 2003; Takakai et al., 2008; Jiang et al., 2015; Smith et al., 2015), but the long-term effects of fire are less investigated (Jiang et al., 2015; Smith et al., 2015; Köster et al., 2017). In our earlier study of Canadian permafrost areas, we observed that it takes more than 50 years for the sites to regain their respective pre-fire thermal conditions (Köster et al., 2017). The same trend can be observed in Siberian permafrost areas, as the soil temperature of the area burned 56 years ago was still significantly higher compared with the area burned more than 100 years ago (Table 1). There was an expected clear correlation between soil temperature and depth of the active layer (the depth of the active layer increases with elevated soil temperatures). Similar results were also obtained by Bond-Lamberty et al. (2016) in interior Alaska. In the area burned 23 years ago the permafrost showed clear signs of recovery as the depth of the active layer had decreased by almost $50 \%$ on average, but 56 years after the fire the depth of the active layer still had not reached its pre-fire levels. In addition, the recovery of the protecting soil organic layer supports the observed 
reduction of the active layer depth. The thickness of the soil organic layer measured in the study area burned 23 years ago was found to be similar to that at the oldest burning site (burned $>100$ years ago) (Table 1 ).

The establishment of vegetation over time allows the ground temperatures to cool down and permafrost to recover (Fisher et al., 2016). Studies from the Canadian permafrost areas showed that the depth of the active layer decreased in correlation with the recovery of ground vegetation in the areas (Fisher et al., 2016; Köster et al., 2017). In Siberian study areas, there was a clear positive correlation between the post-fire recovery of the vegetation and the thickness of the soil organic layer (S. 2). The coverage of vascular plants, mosses, and lichens was significantly lower in the recently burned areas compared with the areas that have had more than 100 years to recover from the last fire (Table 1). The recovery of the ground vegetation took more than 25 years in our study areas, but changes in the species composition between mosses, lichens, and vascular plants continued for a much longer period of time (Table 1). The recovery of the living tree biomass took even longer as there was still significantly less living tree biomass in the areas burned 56 years ago compared with the area burned more than 100 years ago. The maximal biomass of larch was measured in the study area where the fire occurred more than 100 years ago, while the biomass of birch and alder trees was highest in the area where the fire occurred 56 years ago (Table 1). These values are strongly affected by the life expectancy of these species, as the life span of both birch and alder is a maximum of 60 to 80 years (Hynynen et al., 2010; Hytönen and Saarsalmi, 2015). The amount of dead wood biomass was expectedly high in the more recently burned areas (one year and 23 years), as stand-replacing fires have resulted in dead and decomposing tree material (Table 1). Although the amount of dead wood biomass decreased over time, it was still significantly higher 56 years after the fire compared with the areas where the fire occurred more than 100 years ago (Table 1 ).

The combustion of the soil organic layer by the fire strongly affects the soil $\mathrm{C}$ and $\mathrm{N}$ storage (Larjavaara et al., 2017; Palviainen et al., 2017; Startsev et al., 2017). The total soil C and N stock was significantly lower in the most recently burned area (one year ago) than in the other areas (Table 1). The amount of $C$ and $N$ increased with time passed since the last fire, being the highest for the area burned more than 100 years ago (Table 1). The recovery of the soil C stock was fast, as less than 25 years after the fire the total soil C was only slightly lower than that in the oldest area, and the difference was not significant. However, the total $\mathrm{N}$ of the soil was significantly lower 
more than 50 years after the fire compared with the area burned more than 100 years ago. Most

of the variation between soil $\mathrm{C}$ and $\mathrm{N}$ in the studied fire areas is driven by the changes in the soil organic layer because most of the C- and N-rich organic layer is combusted in the fire. However, even the mineral soil $\mathrm{C}$ and $\mathrm{N}$ content was significantly lower shortly after the fire (area burned one year ago) (Table 2). The possible explanation for this could be that the heat induced by fire also affects the top layers of the mineral soil, with combustion releasing $\mathrm{C}$ and $\mathrm{N}$.

Fire-induced changes in soil temperature strongly affect the soil moisture content - another important soil property. Our results show that the oldest area had the highest moisture content in the soil surface, whereas the driest soils were observed in the most recently burned area (Table 1). These findings are similar to those observed by a couple of previous studies dealing with permafrost areas in China (Liang et al., 1991) and in Canada (Köster et al., 2017). Our results can be influenced by the fact that the soil moisture was measured in the top soils, and lower soil moisture in this layer (Table 1) can be caused by the hydrophobic soil surface layers introduced by the fire (Doerr et al., 2009) and by the post-fire higher soil temperatures (Table 1). Still, there are several studies that have documented an increase in soil moisture shortly after a forest fire in Alaska and eastern Siberia (Yoshikawa et al., 2003; Takakai et al., 2008; Jiang et al., 2015) or have observed no changes in it (Oertel et al., 2016). Soil moisture could remain stable after the fire occasion because decreased plant transpiration compensates for the reduction of a protective plant canopy (Oertel et al., 2016), which prevents an increase in soil temperature due to the shading effect of the higher leaf area (Kim, 2013; Fisher et al., 2016).

Similarly to Startsev et al. (2017), the soil pH of our recently burned areas was slightly more alkaline compared with the areas with a longer time interval since the last forest fire, and the higher $\mathrm{pH}$ values were characteristic only for the top $5 \mathrm{~cm}$ layer of the soil (Table 1). These results were expected, as the alkaline ashes deposited on the ground influence only the soil surface (Pereira et al., 2013).

\subsection{Fire impact on carbon dioxide flux}

Forest fires had a significant effect on soil $\mathrm{CO}_{2}$ flux in our study. The $\mathrm{CO}_{2}$ efflux is strongly influenced by the fire-affected factors described in the previous section, such as soil temperature, soil moisture as well as the $\mathrm{C}$ and $\mathrm{N}$ stock of the soil (Oertel et al., 2016). In addition, vegetation 
fires introduce a substantial amount of charred necromass into the soil (Knicker, 2007). Charcoal created by the partial combustion of the organic materials is resistant to the decomposition, and therefore has the potential to influence the soil GHG fluxes; it may also act as a C sink (Knicker, 2007; Kim, 2013; Pereira et al., 2013). Many earlier studies have documented that $\mathrm{CO}_{2}$ efflux reaches its pre-fire level within less than a decade (Burke et al., 1997; Köster et al., 2015), but in the permafrost areas recovery time may be much longer (Köster et al., 2017).

The soil $\mathrm{CO}_{2}$ efflux was significantly lower in the most recently burned area, only about $75 \%$ of that in the oldest area. Based on our recent study conducted in northwestern Canada, the $\mathrm{CO}_{2}$ efflux was also lowest shortly after the fire, and the emission rate started to increase after a few years (Köster et al., 2017). The same trend was also observed in fire areas on non-permafrost soil in northern Finland, where the $\mathrm{CO}_{2}$ efflux was still about 50\% lower three years after the fire compared with the control areas (Köster et al., 2014, 2017).

The stand-replacing fires in our study area destroyed the insulating organic surface layer, which is found to significantly affect the $\mathrm{C}$ and $\mathrm{N}$ storage of the soil (Larjavaara et al., 2017; Palviainen et al., 2017; Startsev et al., 2017). During the fire, a significant amount of covering organic layer is combusted (Nakano, 2006), which also could be observed in our most recent study areas (forest fire one year before measurements) (Table 1). Recent studies have documented that the losses of $\mathrm{C}$ from the burning of the forest floor correspond to soil $\mathrm{CO}_{2}$ efflux of several years (Köster et al., 2014, 2017). Also, the slow recovery of the amount of the decomposing organic matter in the organic layer (combusted in the fire) is known to be an important cause of the decrease in $\mathrm{CO}_{2}$ emissions (Köster et al., 2014).

The changes in soil temperature are considered to be an important factor explaining various gas emissions from the soil (Bond-Lamberty et al., 2016; Oertel et al., 2016), and both laboratory and field experiments have documented temperature-caused changes in $\mathrm{CO}_{2}$ flux (Fang and Moncrieff, 2001; Bond-Lamberty et al., 2016). According to our results, higher soil temperatures in the more recently burned areas did not result in higher $\mathrm{CO}_{2}$ emissions (Table 1, Fig. 2). Instead we observed a clear increasing trend in $\mathrm{CO}_{2}$ efflux with time since the last fire until the forest was 56 years old (Fig. 2). So, we can claim that the temperature alone does not explain the soil $\mathrm{CO}_{2}$ flux, but the development of vegetation and accompanying increase in root respiration should also be taken into account. We found that the soil C stock of the area burned one year ago was $74 \%$ smaller compared with the oldest burning area (Table 1), and the decrease in $\mathrm{CO}_{2}$ efflux was about $75 \%$. 
Earlier studies have reported post-fire reduction of $\mathrm{CO}_{2}$ efflux of about $40-60 \%$ (Kasischke and Stocks, 2000; Richter et al., 2000; Sullivan et al., 2011).

According to the mixed effect model analysis there were four factors $(\mathrm{pH}$ of the top $5 \mathrm{~cm}$ of soil, tree biomass of birch and alder, and ground vegetation biomass of vascular plants) that significantly affected the emission of $\mathrm{CO}_{2}$ (Table 3). Based on earlier studies, we expected that the time since the last fire would be a significant factor in determining $\mathrm{CO}_{2}$ emissions (Kasischke and Stocks, 2000; Richter et al., 2000; Sullivan et al., 2011; Köster et al., 2014, 2017). However, in our current study, the time since the fire explained only $13 \%$ of the variation in the $\mathrm{CO}_{2}$ emissions.

The $\mathrm{pH}$ value in the top $5 \mathrm{~cm}$ of the soil was a significant factor that distinguished the areas in terms of $\mathrm{CO}_{2}$ emissions (Table 3). Soil $\mathrm{pH}$ influences the availability of nutrients and thus it regulates both vegetation biomass production and the growth of microorganisms (Bot and Benites, 2005). Acidic soil conditions can result in lower soil $\mathrm{CO}_{2}$ emissions, and the optimal $\mathrm{pH}$ for $\mathrm{CO}_{2}$ emissions is considered to be neutral (Oertel et al., 2016). In addition, the litter of certain plant species (e.g., shrubs and conifers) has a lower $\mathrm{pH}$ and contains specific phenolic compounds that are difficult to decompose (Adamczyk et al., 2016). In our case the results did not support that, as the highest $\mathrm{CO}_{2}$ emissions were measured from the area burned 56 years ago, which had the most acidic soil pH (Table 1). The area that was most recently burned had the most alkaline $\mathrm{pH}$ but the lowest $\mathrm{CO}_{2}$ efflux. Still, the variation in $\mathrm{pH}$ values in our study areas was minimal, with measured values varying between 5.1 and 5.8, which is rather acidic, compared with a suggested optimal $\mathrm{pH}$ (neutral) for the $\mathrm{CO}_{2}$ emissions (Oertel et al., 2016). The variation was minimal between the studied age classes (Table 1).

The biomass of birch and alder trees also distinguished the areas in terms of $\mathrm{CO}_{2}$ flux, while the dominant larch tree biomass was found to be insignificant in explaining the $\mathrm{CO}_{2}$ emissions in our study areas (Table 3, Model 6). Earlier studies on the species-specific characteristics of root respirations have revealed that the root respiration of birch is about two times higher compared with larch (Eidmann, 1943; Assmann, 1970). Higher root respiration of broad-leaved trees, such as birch and alder compared with conifers, has also been observed (Pumpanen et al., 2009, 2012). Also, the litter coming from broad-leaved trees, such as birch and alder, is easier to decompose (Cornelissen, 1996). Compared with coniferous litter, it contains more $\mathrm{N}$ and less phenolic compounds, which increases the microbial populations and rates of decomposition (Cornelissen, 1996; Prescott et al., 2011). Birches are also known for their shorter life span compared with many 
other trees, lasting a maximum of 60 to 80 years (Hynynen et al., 2010; Hytönen and Saarsalmi, 2015). Our observations revealed that the tree biomass of the birch and alder was significantly higher in the area burned 56 years ago (Table 1). Also, the highest values of $\mathrm{CO}_{2}$ efflux were measured in this area (Fig. 2). In the oldest burning area the larch trees were dominant and the proportion of broad-leaved trees had reduced due to the stand age; the emissions of $\mathrm{CO}_{2}$ were also found to be lower. So based on these results we can claim that the changes in the species composition caused by succession of the stand have a significant impact on the rate of the $\mathrm{CO}_{2}$ emissions.

The fourth factor explaining the soil $\mathrm{CO}_{2}$ emissions was the ground vegetation biomass (Table 3, Model 6). Missing vegetation and root respiration (changed balance between autotrophic and heterotrophic respiration in soil) are often witnessed to cause a reduction in soil $\mathrm{CO}_{2}$ emissions (Kim, 2013; Kulmala et al., 2014; Oertel et al., 2016). We measured the lowest $\mathrm{CO}_{2}$ emissions from the area burned one year ago, which was also characterized by missing vegetation (Table 1) and therefore also the impact of root respiration. As soon as the vegetation and root system recover (in our case in about 25 years), the emissions of $\mathrm{CO}_{2}$ also increase to the same level as in the area burned more than 100 years ago (Table 1, Fig. 2). Our results are similar to those of Köster et al. (2017), who showed that in permafrost areas the recovery of the $\mathrm{CO}_{2}$ flux takes longer than generally thought, and was assumed to correlate with the longer succession of the vegetation and the recovery of the active layer depth.

\subsection{Fire impact on methane flux}

The soil of all investigated areas acted as a $\mathrm{CH}_{4}$ sink. The flux of $\mathrm{CH}_{4}$ between soil and the atmosphere is the net sum of the consumption and production of this GHG (Conard, 1995). The direction and rate of the $\mathrm{CH}_{4}$ flux is controlled by several factors such as soil moisture, soil temperature, and the chemical properties of the soil (Megonigal et al., 2004; Nakano, 2006). However, the latter results are controversial, as Bond-Lamberty et al. (2016) observed no effect of temperature and moisture changes on $\mathrm{CH}_{4}$ fluxes from permafrost soils of interior Alaska. In welldrained and dry arctic and boreal soils such as in our study areas, methanotrophic microorganisms use $\mathrm{CH}_{4}$ as their energy source (Megonigal et al., 2004), which makes these soils $\mathrm{CH}_{4}$ sinks (Fiedler 
et al., 2005; Oertel et al., 2016). In dry northern soils such as in our study areas, the main limiting factor for $\mathrm{CH}_{4}$ oxidation is considered to be the availability of $\mathrm{CH}_{4}$.

According to our results, the time since the last fire explained only a minimal amount of variation in the $\mathrm{CH}_{4}$ flux, and the difference between the areas was not statistically significant, although the most recently burned area seemed to have slightly higher influx compared with the other areas (Fig. 3). Most previous studies have reported the highest uptake of $\mathrm{CH}_{4}$ shortly after the fire (Burke et al., 1997; Takakai et al., 2008; Sullivan et al., 2011; Kim, 2013; Kulmala et al., 2014; Köster et al., 2015; Song et al., 2017). Weak $\mathrm{CH}_{4}$ emissions turned into $\mathrm{CH}_{4}$ influxes in northeastern Chinese boreal forests with continuous permafrost after the forest fire (Song et al., 2018), supporting the notion that fire affects $\mathrm{CH}_{4}$ fluxes. However, the previous work of Song et al. (2017) revealed that the topography has a stronger impact on $\mathrm{CH}_{4}$ fluxes compared with the fire disturbance.

Fire-induced changes in soil conditions change soil microbial community composition, and affect the GHG production and consumption in soil (Sun et al., 2016). Soil moisture has a significant impact on $\mathrm{CH}_{4}$ flux, as strictly anaerobic conditions are required for $\mathrm{CH}_{4}$ production (Oertel et al., 2016). $\mathrm{CH}_{4}$ oxidation processes are less dependent on soil moisture, but previous studies have reported the moisture sensitivity of $\mathrm{CH}_{4}$-oxidizing bacteria (Conard, 1995; Whalen and Reeburgh, 1996). The sensitivity of $\mathrm{CH}_{4}$-oxidizing bacteria to the water stress is highly dependent on the investigated environments (Whalen and Reeburgh, 1996). In our study, there was no correlation between the soil moisture and $\mathrm{CH}_{4}$ flux (S. 2). The soil moisture in the studied areas was in the range $23.6-40.1 \%$ (Table 1), which is considered to be an optimum for $\mathrm{CH}_{4}$ oxidation in boreal soils (Whalen and Reeburgh, 1996). The significantly lower soil moisture content measured in the most recently burned area (Table 1) slightly increased the $\mathrm{CH}_{4}$ sink of, but it was not significantly higher when compared with the oldest burning area (Fig. 3).

Recently, several studies have stressed the significance of vegetation in increasing the $\mathrm{CH}_{4}$ emissions (Keppler et al., 2006; Mukhin and Voronin, 2011; Covey et al., 2012; Lenhart et al., 2015). As forest fires significantly affect the ground vegetation composition, the effect on the $\mathrm{CH}_{4}$ emissions should be rather large. Lenhart et al. (2015) also pointed out that the emissions of $\mathrm{CH}_{4}$ from cryptogams are temperature dependent, which in the course of global warming might lead to an increase in $\mathrm{CH}_{4}$ emissions from lichens and mosses (Porada et al., 2017). From this perspective the highest influx of $\mathrm{CH}_{4}$ measured in the most recently burned study area (Fig. 3) 
could be caused by the missing vegetation (Table 1), and the lower $\mathrm{CH}_{4}$ influx in the area burned 56 years ago could be caused by the increased $\mathrm{CH}_{4}$ emissions from the ground vegetation cover. On the other hand, the vegetation and its rhizosphere provide an oxidizing environment, and should result in an increased influx of $\mathrm{CH}_{4}$ (Ström et al., 2005; Fritz et al., 2011). Our results did not support that, as the growth of ground vegetation decreased the $\mathrm{CH}_{4}$ influx in our study areas (Table 1, Fig. 3). Still, observed changes in $\mathrm{CH}_{4}$ flux seem to depend on the changes in aboveground vegetation communities.

\section{CONCLUSIONS}

We studied the long-term effects of fire on the fluxes of two main C-based $\mathrm{GHGs}\left(\mathrm{CO}_{2}\right.$ and $\left.\mathrm{CH}_{4}\right)$ in boreal coniferous forest areas with underlying permafrost. Consistent with our hypothesis the fluxes of $\mathrm{CO}_{2}$ have changed as a consequence of fire. Our results confirm that fire significantly affected the fluxes of $\mathrm{CO}_{2}$, and the impact of fire lasted much longer than expected based on previous studies. There was a significant decrease in soil $\mathrm{CO}_{2}$ efflux shortly after the fire, but over time the emissions started to increase and this increase continued for more than 50 years after the fire. It can therefore be assumed that the flux of $\mathrm{CO}_{2}$ had not yet stabilized during that time. The effect of fire on the $\mathrm{CH}_{4}$ flux was not significant in Siberian boreal forest with a permafrost base, but all the studied areas acted as a $\mathrm{CH}_{4}$ sink. One of our hypotheses was that the fluxes of $\mathrm{CO}_{2}$ and $\mathrm{CH}_{4}$ are positively correlated with the depth of the active layer on top of the permafrost during the vegetation period. There was a clear negative correlation between $\mathrm{CO}_{2}$ emissions and depth of the active layer, while $\mathrm{CH}_{4}$ fluxes were not influenced by it. The third hypothesis was that the recovery of the $\mathrm{CO}_{2}$ and $\mathrm{CH}_{4}$ fluxes to the pre-fire levels is related to the recovery of the vegetation. Our results confirmed that the role of recovering vegetation in $\mathrm{CO}_{2}$ emissions is significant as the main factors driving the $\mathrm{CO}_{2}$ flux were the biomass of birch and alder trees, and the biomass of the vascular plants in the ground vegetation.

\section{ACKNOWLEDGEMENTS}

This study was supported by the Academy of Finland (Project Nos 286685, 294600, 307222), the Integrated Carbon Observation System (ICOS) Finland (281255), and by the European Union 
project GHG-LAKE (612642). We are grateful to Cathryn Primrose-Mathisen for her English language assistance. 


\section{REFERENCES}

Akaike, H. 1998. Information Theory and an Extension of the Maximum Likelihood Principle BT -

Selected Papers of Hirotugu Akaike. In: Parzen, E. Tanabe, K. \& Kitagawa, G. (Eds.) New York, Springer New York, pp. 199-213, doi: 10.1007/978-1-4612-1694-0_15

Alexeyev, V., Birdsey, R.A., Stakanov, V., Korotkov, I., 1995. Carbon in vegetation of Russian forests: methods to estimate storeage and geographical distribution. Water, Air and Soil Pollution, 82: 271-282, doi: 10.1007/BF01182840

Anisimov, O., Reneva, S., 2006. Permafrost and changing climate: The Russian perspective. Ambio, 35(4): 169-175. https://www.jstor.org/stable/4315715

Assmann, E., 1970. The Principles of Forest Yield Study: Studies in the Organic Production, Structure, Increment and Yield of Forest Stands. Pergamon Press Ltd. 506 p.

Adamczyk, B., Ahvenainen, A., Sietiö, O-M., Kanerva, S., Kieloaho, A.-J., Smolander, A., Kitunen, V., Saranpää, P., Laakso, T., Strakova, P., Heinonsalo, J. 2016. The contribution of ericoid plants to soil nitrogen chemistry and organic matter decomposition in boreal forest soil. Soil Biology and Biochemistry, 103: 394-404, doi: 10.1016/j.soilbio.2016.09.016

Bates, D., Maechler, M., Bolker, B., Walker, S., 2015. Fitting Linear Mixed-Effects Models Using Ime4. Journal of Statistical Software, 67(1): 1-48, doi: 10.18637/jss.v067.i01.

Bond-Lamberty, B., Smith, A.P., Bailey, V., 2016. Temperature and moisture effects on greenhouse gas emissions from deep active-layer boreal soils. Biogeosciences, 13: 6669-6681. doi: 10.5194/bg13-6669-2016

Bot, A., Benites, J., 2005. The importance of soil organic matter. Key to drought-resistant soil and sustained food and production. FAO Soils Butteltin, 80: p. 80.

Brown, R. J. E., 1983. Effects of fire on permafrost ground thermal regime. In: The Role of Fire in Northern Circumpolar Ecosystems, R.W. Wein, and D.A. MacLean (Eds.), John Wiley, New York, pp. 97-110.

Brown, J., Rerrians Jr., O.J., Heginbottom, J.A., Melnikov, E.S., 1997. Circum-Arctic map of permafrost and ground-ice conditions, USGS Circum-Pacific Map Series CP-45, (scale $1: 10,000,000)$. 
Burke, R.A., Zepp, R.G., Tarr, M.A., Miller, W.L., Stocks, B.J., 1997. Effect of fire on soil-atmosphere exchange of methane and carbon dioxide in Canadian boreal forest sites. Journal of Geophysical Research, 102(D24): 29287-28300, doi: 10.1029/97JD01331

Chambers, J.M., 1992. Linear models. In: J.M. Chambers and T.J. Hastie (Eds.), Chapter 4 of statistical models in S. Wadsworth and Brooks/Cole, Pacific Grove, California.

Conard, R., 1995. Soil microbial processes involved in production and consumption of atmospheric trace gases. Advances in Microbial Ecology, 14: 207-250, doi: 10.1098/rsta.1995.0030

Cornelissen, J.H.C., 1996. An experimental comparison of leaf decomposition rates in a wide variety of temperate plant species and types. Journal of Ecology, 84(4): 573-582, doi: $10.2307 / 2261479$

Covey, K.R., Wood, S.A., Warren II, R.J., Lee, X., Bradford, M.A., 2012. Elevated methane concentrations in trees on an upland forest. Geophysical Research Letters, 39: L15705, doi: $10.1029 / 2012$ GL052361

Doerr, S.H., Shakesby, R.A., MacDonald, L.H., 2009. Soil water repellency: a key factor in post-fire erosion? In: Cerda, A., Fobinchaud, P. (Eds.), Restoration strategies after forest fires. CRC Press, pp. 197-225.

Dyrness, C.T., 1982. Control of depth to permafrost and soil temperature by the forest floor in black spruce/feathermoss communities. Res. Note PNW-RN-396. Portland, OR: U.S. Department of Agriculture, Forest Service, Pacific Northwest Forest and Range Experiment Station. 19 p, doi: 10.2737/PNW-RN-396

Eidmann, F.E., 1943. Untersuchungen über die Wurzelatmung und Transpiration unserer Hauptholzarten. Schriftenr. der Herman-Göring-Akad. Deutschland. Forstwiss. 5 (in German).

Fan, S., Gloor, M, Mahlman, J., Pacala, S., Sarmiento, J., Takashi, T., Peng, T., 1998. A large terrestrial carbon sink in North America implied by atmospheric and oceanic carbon dioxide data and models. Science, 282, 442-446, doi: 10.1126/science.282.5388.442

Fang, C., Moncrieff, J.B., 2001. The dependence of soil $\mathrm{CO}_{2}$ efflux on temperature. Soil Biology and Biochemistry, 33: 155-165, doi: 10.1016/S0038-0717(00)00125-5

Faraway, J.J., 2002. Practical Regression and Anova using R. In: Reproduction. pp. 88-91. 
Fiedler, S., Höll, B.S., Jungkunst, H.F., 2005. Methane budget of a black forest spruce ecosystem considering soil pattern. Biogeochemistry, 76(1): 1-20, doi: 10.1007/s10533-005-5551-y

Fisher, J.P., Estop-Aragonés C., Thierry, A., Charman D.J., Wolfe, S.A., Hartley, I.P., Murton, J.B., Williams, M., Phoenix, G.K., 2016. The influence of vegetation and soil characteristics on active-layer thickness of permafrost soils in boreal forest. Global Change Biology, 22: 3127-3140, doi: $10.1111 / g c b .13248$

Flannigan, M.D., Stocks, B.J., Wotton, B.M., 2000. Climate change and forest fires. The Science of the Total Environment, 262: 221-229, doi: 10.1016/S0048-9697(00)00524-6

Flannigan, M., Stocks, B., Turetsky, M., and Wotton, M., 2009. Impacts of climate change on fire activity and fire management in the circumboreal forest. Global Change Biology, 15: 549-560.

Fritz, C. Pancotto, V.A., Elzenga J.T., Visser, E.J., Grootjans, A.P., Pol, A., Iturraspe, R., Roelofs, J.G., Smolders, A.J., 2011. Zero methane emission bogs: extreme rhizosphere oxygenation by cushion plants in Patagonia. New Phytologist, 190: 398-408, doi: 10.1111/j.1469-8137.2010.03604.

Ganteaume, A., Camia, A., Jappiot, M., San-Miguel-Ayanz, J., Long-Fournel, M., Lampin, C., 2013. A review of the main driving factors of forest fire ignition over Europe. Environmental Management, 51: 651-662. doi: 10.1007/s00267-012-9961-z

Grosse, G., Harden, J., Turetsky, M., McGuire, A.D., Camill, P., Tarnocai, C., Frolking, S., Schuur, E.A.G., Jorgenson, T., Marchenko, S., Romanovsky, V., Wickland, K.P., French, N., Waldrop, M., Bourgeau-Chavez, L., Striegl, R.G., 2011. Vulnerability of high-latitude soil organic carbon in North America to disturbance. Journal of Geophysical Research: Biogeosciences, 116: G00K06, doi: $10.1029 / 2010 J G 001507$

Hütsch, B.W., Webster, C.P., Powlson, D.S., 1994. Methane oxidation in soil as affected by land use, soil pH and $\mathrm{N}$ fertilization. Soil Biology and Biochemistry, 26(12): 1613-1622, doi: $10.2136 /$ sssaj2004.0223

Hynynen, J., Niemistö, P., Viherä-Aarnio, A., Brunner, A., Hein, S., Velling, P., 2010. Silviculture of birch (Betula pendula Roth and Betula pubescens Ehrh.) in northern Europe. Forestry: An International Journal of Forest Research, 83: 103-119. 
Hytönen J., Saarsalmi A., 2015. Biomass production of coppiced grey alder and the effect of fertilization. Silva Fennica 49: id 1260. doi: 10.14214/sf.1260

Iglewicz, B., Hoaglin D., 1993. How to Detect and Handle Outliers. In: Mykytka, E.F. (Ed.), The ASQC Basic References in Quality Control: Statistical Techniques, Vol. 16.

IUSS Working Group WRB, 2006. World Reference Base for Soil Resources 2006. World Soil Resources Reports no. 103. FAO, Rome.

James, G., Witten, D., Hastie, T., Tibshirani, R., 2000. An introduction to Statistical Learning. Current medicinal chemistry, Vol. 7, doi: 10.1007/978-1-4614-7138-7

Jiang, Y., Rocha, A. V., O’Donnell, J. A., Drysdale, J. A., Rastetter, E. B., Shaver, G. R., Zhuang, Q. 2015. Contrasting soil thermal responses to fire in Alaskan tundra and boreal forest. Journal Geophysical Research: Earth Surface, 120: 363-378, doi: 10.1002/2014JF003180

Jorgenson, M.T., Romanovsky, V., Harden, J., Shur, Y., O’Donnell, J., Schuur, E.A.G., Kanevskiy, M., Marchenko, S., 2010. Resilience and vulnerability of permafrost to climate change. Can. J. Forest Res. 40(7): 1219-1236, doi: 10.1139/X10-060

Kasischke, E.S., Christensen, N.L., Jr., Stocks, B.J., 1995. Fire, global warming, and the carbon balance of boreal forests. Ecol. Appl., 5(2): 437-451, doi: 10.2307/1942034

Kasischke, E.S., Stocks, J.B. (Eds.), 2000. Fire, Climate Change, and Carbon Cycling in the Boreal Forest, Ecological Studies 138, Springer-Verlag, New York, 461 pp.

Karpachevskiy, M., 2004. Forest Fires in the Russian Taiga: Natural Disaster or Poor Management? Taiga rescue network fact sheet - December 2004, 8 p.

Keppler, F., Hamilton, J.T.G., Braß, M., Röckmann, T., 2006. Methane emissions from terrestrial plants under aerobic conditions. Nature, 439: 187-191, doi: 10.1038/nature04420

Kharuk, V.K., Ranson, K.J., Dvinskaya, M.L., Im, S.T., 2011. Wildfires in northern Siberian larch dominated communities. Environmental Research letters, 6: 045208 (6pp), doi: 10.1088/17489326/6/4/045208

Kim, Y.-S., 2013. Soil-Atmosphere Exchange of $\mathrm{CO}_{2}, \mathrm{CH}_{4}$ and $\mathrm{N}_{2} \mathrm{O}$ in Northern Temperate Forests: Effects of Elevated $\mathrm{CO}_{2}$ Concentration, $\mathrm{N}$ Deposition and Forest Fire. Eurasian Journal of Forest Research, 16(1), 1-43. 
Kim, Y., Tanaka, N., 2003. Effect of forest fire on the fluxes of $\mathrm{CO}_{2}, \mathrm{CH}_{4}$ and $\mathrm{N}_{2} \mathrm{O}$ in boreal forest soils, interion Alaska. Journal of Geophysical Research, 108, NO.D1, 8154, FFR 10-1 - FRR 10-11. doi: $10.1029 / 2001 J D 000663$

Knicker, H., 2007. How does fire affect the nature and stability of soil organic nitrogen and carbon? A review. Biogeochemistry 85: 91-118, doi: 10.1007/s10533-007-9104-4

Köster, E., Köster, K., Berninger, F., Pumpanen, J., 2015. Carbon dioxide, methane and nitrous oxide fluxes from podzols of a fire chronosequence in the boreal forests in Värriö, Finnish Lapland. Geoderma Regional 5: 181-187, doi: 10.1016/j.scitotenv.2017.05.246

Köster, E., Köster, K., Berninger, F., Aaltonen, H., Zhou, X., Pumpanen, J., 2017. Carbon dioxide, methane and nitrous oxide fluxes from a fire chronosequence in subarctic boreal forest of Canada. Science of the Total Environment 601-602: 895-905, doi: 10.1016/j.scitotenv.2017.05.246

Köster, K., Berninger, F., Lindén, A., Köster, E., Pumpanen, J., 2014. Recovery in fungal biomass is related to decrease in soil organic matter turnover time in a boreal fire chronosequence. Geoderma 235-236: 74-82, doi: 10.1016/j.geoderma.2014.07.001

Kulmala L., Aaltonen H., Berninger F., Kieloaho A.-J., Levula J., Bäck J., Kolari P., Korhonen J.F.J., Nikinmaa E., Pihlatie M., Vesala T., Pumpanen J., 2014. Changes in biogeochemistry and carbon fluxes in a boreal forest after a clear cut and partial burning of slash. Agricultural and Forest Meteorology, 188: 33-44, doi: 10.1016/j.agrformet.2013.12.003

Kwon, M.J., Heimann, M., Kolle, O., Luus, K.A.,Schuur, A.G., Zimov, N., Zimov, S.A., Göckede, M., 2016. Long-term drainage reduces $\mathrm{CO}_{2}$ uptake and increases $\mathrm{CO}_{2}$ emission on a Siberian floodplain due to shifts in vegetation community and soil thermal characteristics. Biogeosciences, 13: 42194235, doi: 10.5194/bg-13-4219-2016

Larjavaara, M., Berninger, F., Palviainen, M., Prokushkin A. Wallenius, T., 2017. Post-fire carbon and nitrogen accumulation and succession in Central Siberia. Scientific Reports, 7: 12776, doi: $10.1038 / s 41598-017-13039-2$

Lenhart, K., Weber, B., Elbert, W., Steinkamp, J., Clough, T., Crutzen, P., Pöschl, U., Keppler, F., 2015. Nitrous oxide and methane emissions from cryptogamic covers. Global Change Biology, 21, 3889-3900, doi: 10.1111/gcb.12995 
Liang, L.-H., Zhou, Y.-W., Wang, J.C., 1991. Changes to the permafrost environment after forest fire, Da Xi'an Ridge, Gu Lian Mining Area, China. Permafrost Periglac., 2: 253-257. doi: 10456740/91/030253-05\$05.00

Megonigal, J.P., Hines, M.E., Visscher, P.T., 2004. Anaerobic Metabolism: Linkages to Trace Gases and Aerobic Processes, in: Schelesinger, W.H. (Ed.) Biogeochemistry. Elsevier-Pergamon, Oxford, UK. pp. 317-424, doi: 10.1016/B0-08-043751-6/08132-9

Morishita, T., Noguchi, K., Kim, Y., Matsuura, Y., 2015. $\mathrm{CO}_{2}, \mathrm{CH}_{4}$ and $\mathrm{N}_{2} \mathrm{O}$ fluxes of upland black spruce (Picea mariana) forest soils after forest fires of different intensity in interior Alaska. Soil Science and Plant Nutrition, 61: 98-105, doi: 10.1080/00380768.2014.963666

Mukhin, V.A., Voronin, P.Y., 2011. Methane emission from living tree wood. Russian Journal of Plant Physiology, 58(2): 344-350, doi: 10.1134/S1021443711020117

Nakano, T., 2006. Changes in surface methane flux after a forest fire in West Siberia, in: Hatano, R., Guggenberger, G. (Eds.), Symptom of Environmental Change in Siberian Permafrost Region. Hokkaido University Press, Sapporo, pp. 55-63.

Oertel, C., Matschullat, J., Zurba, K., Zimmermann, F., Erasmi, S., 2016. Greenhouse gas emissions from soils - A review. Chemie der Erde - Geochemistry, 76(3): 327-352, doi: 10.1016/j.chemer.2016.04.002

Osawa A., Zyryanova, O.A., 2010. Introduction. In: Osawa, A., Zyryanova, O.A., Matsuura, Y., Kajimoto, T., Wein, R.W. (Eds.), Permafrost Ecosystems: Siberian Larch Forests. Springer, Berlin, pp. 3-16.

Palviainen, M., Pumpanen, J., Berninger, F., Ritala, K., Duan, B., Heinonsalo, J., Sun, H., Köster, E., Köster, K., 2017., Nitrogen balance along a nortern boreal forest fire chronosequence. PLoS One, 12(3): e0174720, doi: 10.1371/journal.pone.0174720

Pereira, P., Cerdá, A., Bolutiene, V., Úbeda, X., Pranskevicius, M., Jordán, A., Zavala, L.M., MataizSolera, J. 2013. Spatio-temporal effects of low severity grassland fire on soil colour. Geophysical Research Abstracts 15, EGU2013-10641.

Pihlatie, M., Christiansen, J.R., Aaltonen, H., Korhonen, J.F.J., Nordbo, A., Rasilo, T., Benanti, G., Giebels, M., Helmy, M., Sheehy, J., Jones. S., Juszczak, R., Klefoth, R., Lobo-do-Vale, R., Rosa, A.P., 
Schreiber, P., Serca, D., Vicca, S., Wolf, B., Pumpanen, J., 2013. Comparison of static chambers to measure $\mathrm{CH}_{4}$ emissions from soils. Agricultural and Forest Meteorology, 171-172: 124-136, doi: 10.1016/j.agrformet.2012.11.008

Ponomarev E.I., Kharuk V.I., Ranson K.J. Wildfires Dynamics in Siberian Larch Forests. Forests 2016, 7(6): 125, doi: 10.3390/f7060125

Porada, P., Pöschl, U., Kleidon, A., Beer, C., Weber, B., 2017. Estimating global nitrous oxide emissions by lichens and bryophytes with a process-based productivity model. Biogeosciences, 14 : 1593-1602, doi: 10.5194/bg-14-1593-2017

Pumpanen, J.S. Heinonsalo, J. Rasilo, T. Hurme, K.-J. Ilvesniemi, H., 2009. Carbon balance and allocation of assimilated $\mathrm{CO}_{2}$ in Scots pine, Norway spruce and silver birch seedlings determined with gas exchange measurements and ${ }^{14} \mathrm{C}$ pulse labelling in laboratory conditions. Trees: Structure and Function, 23: 611-621, doi: 10.1007/s00468-008-0306-8

Pumpanen, J., Heinonsalo, J., Rasilo, T., Villemot, J., Ilvesniemi, H., 2012. The effects of soil and air temperature on $\mathrm{CO}_{2}$ exchange and net biomass accumulation in Norway spruce, Scots pine and silver birch seedlings. Tree Physiology, 32(6): 724-736, doi: 10.1093/treephys/tps007

Prescott, C., Zabek, L.M., Staley, C.L., Kabzems, R., 2011. Decomposition of broadleaf and needle litter in forest of British Columbia: influences of litter type, forest type, and litter mixtures. Canadian Journal of Forest Research, 30 (11): 1742-1750, doi: 10.1139/cjfr-30-11-1742

Prokushkin, A. S., Gavrilenko, I. V., Abaimov, A. P., Prokushkin, S. G., Samusenko, A. V., 2006. Dissolved Organic Carbon in Upland Forested Watersheds Underlain by Continuous Permafrost in Central Siberia, Mitigation and Adaptation Strategies for Global Change 11: 223-240, doi: $10.1007 / \mathrm{s} 11027-006-1022-6$

Repola, J., 2008. Biomass equations for birch in Finland. Silva Fennica, 42: 605-624, doi: $10.14214 /$ sf.236

Richter, D.D., O'Neill, K.P., Kasischke, E.S., 2000. Postfire stimulations of microbial decomposition in black spruce (Picea marinara L.) forest soils, in: Kasischke E.S., Stocks, B.J., (Eds.), A Hypothesis, in Fire, Climate Change, and Carbon Cycling in the Boreal Forest. Springer-Verlag, New York, pp. 197-213. 
Smith, S.L., Risenborough, D.W., Bonnaventure, P.P., 2015. Eighteen years record of forest fire effects on ground thermal regimes and permafrost in the Central Mackenzie Valley, NWT, Canada. Permafrost and Periglacial Processes, 26(4): 289-303.

Song, X., Wang, G., Hu, Z., Ran, F., Chang, R., Song, C., Xiao, Y., 2017. Effects of topography and fire on soil $\mathrm{CO} 2$ and $\mathrm{CH} 4$ flux in boreal forest underlain by permafrost in northeast China. Ecological Engineering, 106(A): 35-43, doi: 10.1016/j.ecoleng.2017.05.033

Song, X., Wang, G., Hu, Z., Ran, F., Chen, X., 2018. Boreal forest soil CO2 and CH4 fluxes following fire and their responses to experimental warming and drying. Science of the Total Environment, 644(10): 862 - 872. doi: 10.1016/j.scitotenv.2018.07.014

Startsev, V.V., Dymov, A.A., Prokushkin, A.S., 2017. Soils of postpyrogenic larch stands in Central Siberia: Morphology, physicochemical properties, and specificity of soil organic matter. Eurasian Soil Science, 50: 885-897, doi: 10.1134/S1064229317080117

Ström, L., Mastepanov, M., Christensen, T.R., 2005. Species-specific effects of vascular plants on carbon turnover and methane emissions from wetlands. Biogeochemistry, 75: 65-82, doi: $10.1007 / \mathrm{s} 10533-004-6124-1$

Sun, H., Santalahti, M., Pumpanen, J., Köster, K., Berninger, F., Raffaello, T., Asiegbu, F.O., Heinonsalo, J., 2016. Bacterial community structure and function shift across a northern boreal forest fire chronosequence. Scientific Reports, 6: 32411, doi: 10.1038/srep32411

Sullivan, B.W., Kolb, T.E., Hart, S.C., Kaye, J.P., Hungate, B.A., Dore, S., Montes-Helu, M., 2011. Wildfire reduces carbon dioxide efflux and increases methane uptake in ponderosa pine forest soils of southwestern USA. Biogeochemistry, 104: 251-265, doi: 10.1007/s10533-010-9499-1

Takakai, F., Desyatkin, A.R., Lopez, L.C.M., Fedorov, A.N., Desyatkin, R.V., Hatano, R., 2008. $\mathrm{CH}_{4}$ and $\mathrm{N}_{2} \mathrm{O}$ emissions from a forest-alas ecosystem in the permafrost taiga forest region, eastern Siberia, Russia. Journal of Geophysical Research, 113: G02002, doi: 10.1029/2007JG000521

Taş, N., Prestat, E., McFarland, J.W., Wickland, K.P., Knight, R., Berhe, A.A., Jorgenson, T., Waldrop, M.P., Jansson, J.K., 2014. Impact of fire on active layer and permafrost microbial communities and metagenomes in an upland Alaskan boreal forest. The ISME Journal, 8: 1904-1919, doi: 10.1038/ismej.2014.36. 
Ullah, S., Moore, T.R., 2011. Biochemical controls on methane, nitrous oxide, and carbon dioxide fluxes from deciduous forest soils in eastern Canadian Journal of Geophysical Researh, 116: G03010, doi: 10.1029/2010JG001525

Urbanski, S.P., Wei Min Hao, W.M., Baker, S., 2009. Chemical Composition of Wildland Fire Emissions. In A. Bytnerowicz, M. Arbaugh, A. Riebau and C. Andersen (Eds.) Developments in Environmental Science, Volume 8, Elsevier B.V. pp. 79-107, doi: 10.1016/S1474-8177(08)00004-1

Viereck, L.A., 1982. Effects of fire and firelines on active layer thickness and soil temperatures in interior Alaska. In: Proceedings of the $4^{\text {th }}$ Canadian Permafrost Conference, The Roger J.E. Brown Memorial Volume, pp. 123-134, Natl. Res. Counc. of Can., Ottawa, Ont., Canada.

Whalen, S.C., Reeburgh, W.S., 1996. Moisture and temperature sensitivity of $\mathrm{CH}_{4}$ oxidation in boreal soils. Soil Biology and Biochemisty, 28(10/11): 1271-1281, doi: 10.1016/S00380717(96)00139-3

Yoshikawa K., Bolton, W.R., Romanovsky, V.E., Fukuda, M., Hinzman, L.D., 2003. Impacts of wildfire on the permafrost in the boreal forests of Interior Alaska. Journal of Geophysical Research, 107(8148), FFR4-1-FFR4-14, doi: 10.1029/2001JD000438.

Zavala, L.M., De Celis, R., Jordan, A., 2014. How wildfires affect soil properties. A brief review. Cuadernos de Investigación Geográfica, 40(2): 311-331.

Zona, D., 2016. Long-term effects of permafrost thaw. Nature, 537: 625-626, doi: $10.1038 / 537625 a$

Websites

Global Forest Atlas, Fire \& the Boreal, Yale School of Forestry \& Environmental Studies, USA. https://globalforestatlas.yale.edu/boreal-forest/boreal-ecoregions-ecology/fire-boreal/ (accessed 11 July 2018). 


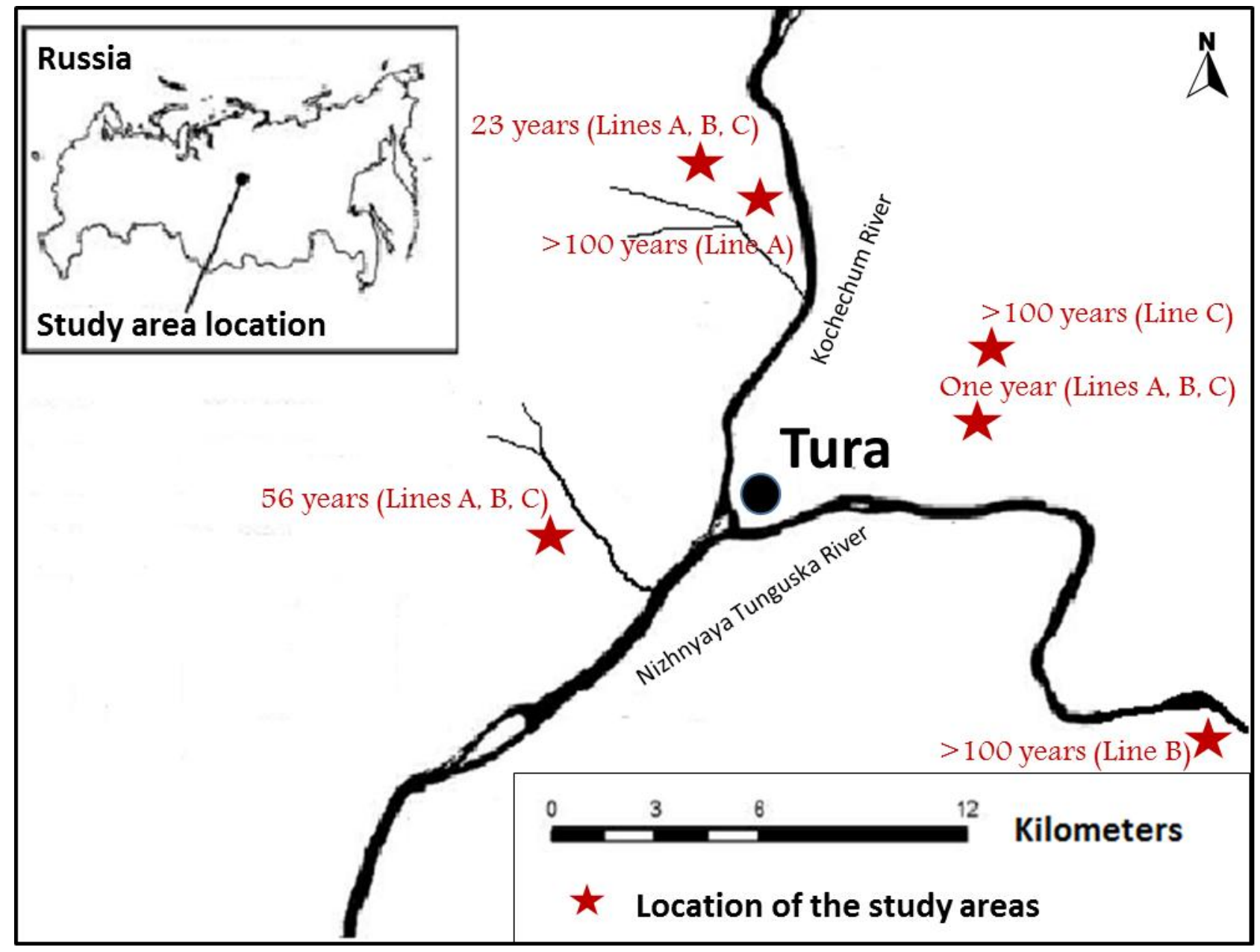

Figure 1. Location of the study areas (time since the last forest fire, years) close to Tura (the Russian Federation) in the northern part of the Central Siberian Plateau, near the Nizhnyaya Tunguska River and its tributary, the Kochechum River. For areas one year, 23 years, and 56 years after the fire, lines $A, B$, and $C$ are at the same location. 
Click here to download Figure: Koster et al_Figure2_revised.docx

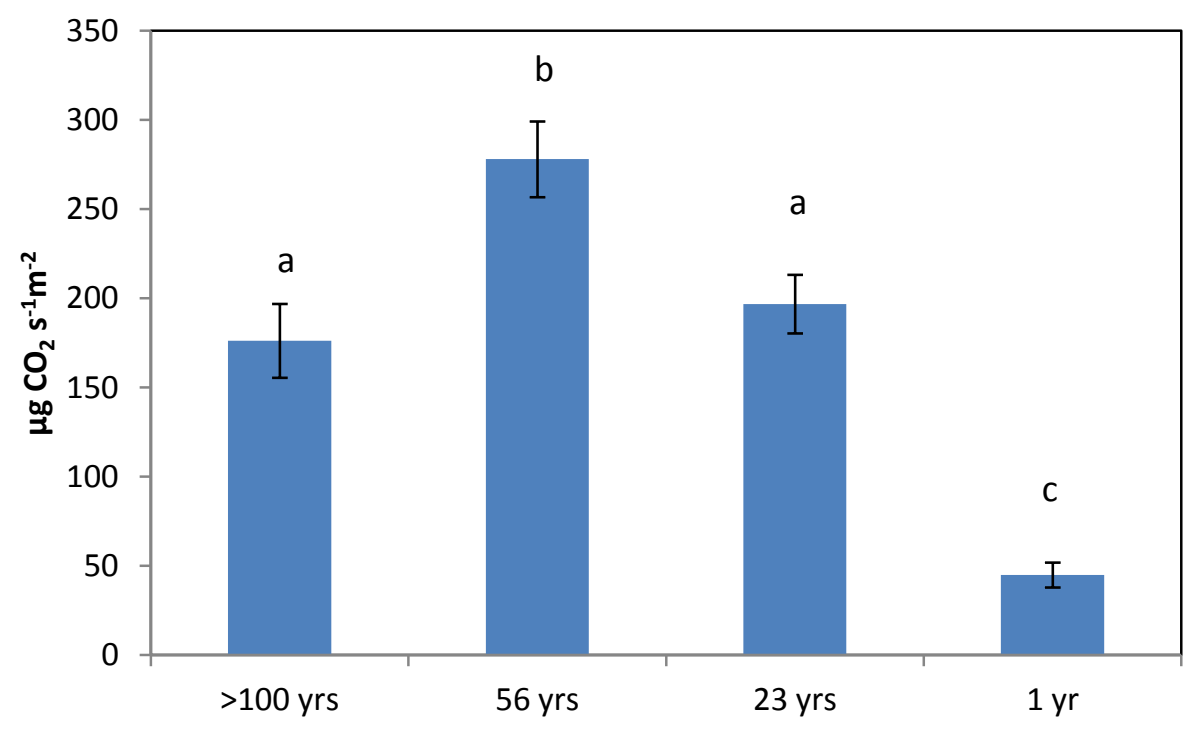

Figure 2. Average carbon dioxide $\left(\mathrm{CO}_{2}\right)$ flux $\left(\mu \mathrm{g} \mathrm{CO}_{2} \mathrm{~m}^{-2} \mathrm{~s}^{-1}\right)(\mathrm{n}=72$ per measurement period) per analyzed fire age class. Vertical bars represent the standard errors. Letters above the bars indicate the statistically significant difference $(p<0.05)$. 
Click here to download Figure: Koster et al_Figure3_revised.docx

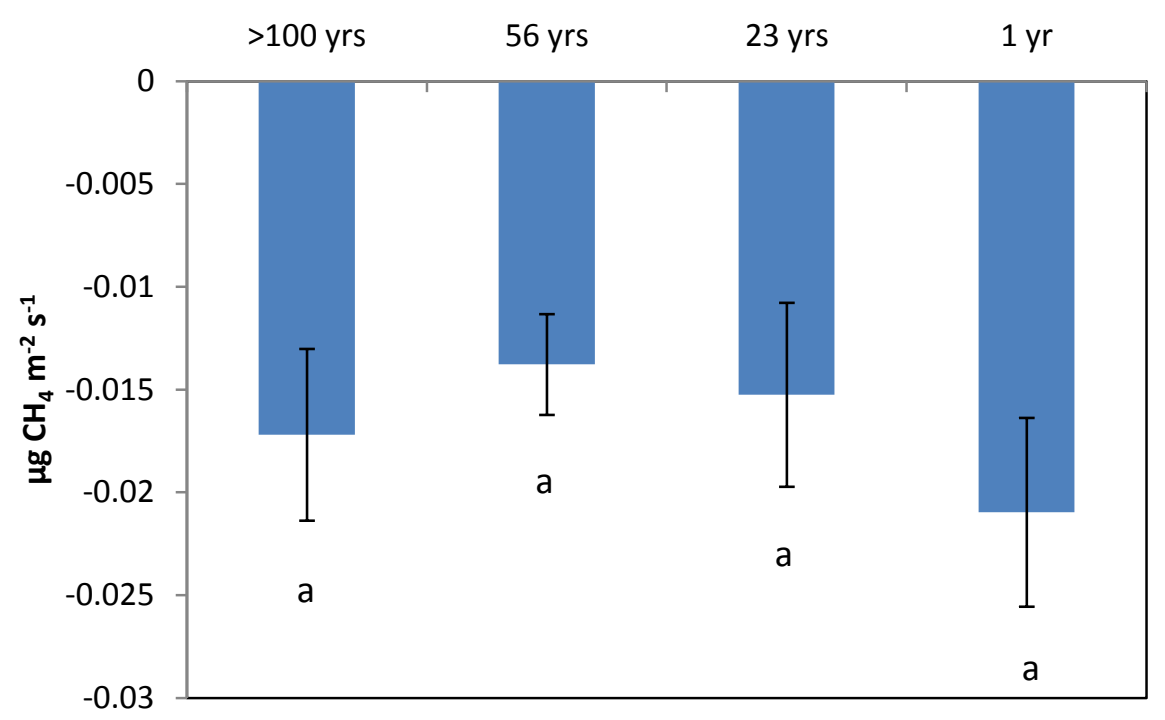

Figure 3. Average methane $\left(\mathrm{CH}_{4}\right)$ flux $\left(\mu \mathrm{C} \mathrm{CH}_{4} \mathrm{~m}^{-2} \mathrm{~s}^{-1}\right)(\mathrm{n}=72$ per measurement period) per analyzed fire age class. Vertical bars represent the standard errors. Letters under the bars indicate the statistically significant difference $(p<0.05)$. 
Click here to download Table: Koster et al_Table 2_revised.docx

Table 2. Carbon (C) and nitrogen $(\mathrm{N})$ storage in the soils of studied fire chronosequence areas.

\begin{tabular}{|c|c|c|c|c|c|c|c|c|}
\hline $\begin{array}{l}\text { Time since } \\
\text { last fire } \\
\text { (years) }\end{array}$ & Layer & $\begin{array}{l}\text { Thickness of } \\
\text { layer }(m)\end{array}$ & $\begin{array}{l}\text { Bulk } \\
\text { density }\end{array}$ & $\begin{array}{c}\text { C concentration } \\
\text { (\%) }\end{array}$ & $\begin{array}{c}\mathrm{N} \text { concentration } \\
\text { (\%) }\end{array}$ & C stock $\left(\mathrm{kg} \mathrm{m}^{-2}\right)$ & $\mathrm{N}$ stock $\left(\mathrm{kg} \mathrm{m}^{-2}\right)$ & $\mathrm{C}: \mathrm{N}$ ratio \\
\hline \multirow[t]{2}{*}{$>100$} & Organic & 0.123 & 0.38 & 12.11 & 0.46 & $4.94 \pm 1.4$ & $0.19 \pm 0.05$ & 25.87 \\
\hline & Mineral & 0.377 & 0.93 & 1.54 & 0.08 & $5.61 \pm 1.0$ & $0.30 \pm 0.04$ & 18.31 \\
\hline \multirow[t]{2}{*}{56} & Organic & 0.103 & 0.45 & 10.08 & 0.34 & $3.89 \pm 0.8$ & $0.14 \pm 0.03$ & 27.46 \\
\hline & Mineral & 0.397 & 0.99 & 0.91 & 0.05 & $3.57 \pm 0.4$ & $0.21 \pm 0.02$ & 17.06 \\
\hline \multirow[t]{2}{*}{23} & Organic & 0.075 & 0.55 & 8.13 & 0.35 & $2.67 \pm 0.5$ & $0.11 \pm 0.02$ & 23.03 \\
\hline & Mineral & 0.425 & 1.07 & 1.22 & 0.06 & $4.88 \pm 1.5$ & $0.28 \pm 0.05$ & 15.61 \\
\hline \multirow[t]{2}{*}{1} & Organic & 0.005 & 0.38 & 12.11 & 0.46 & $0.26 \pm 0.1$ & $0.01 \pm 0.005$ & 17.23 \\
\hline & Mineral & 0.495 & 0.92 & 0.60 & 0.04 & $2.71 \pm 0.3$ & $0.19 \pm 0.02$ & 13.87 \\
\hline
\end{tabular}



Table 1. Mean values of soil temperature (soil temp), soil moisture, soil pH, soil carbon and nitrogen stocks, depth of active layer, thickness of soil organic layer, ground vegetation biomass and coverages, and living tree biomasses for alder, birch and larch and dead wood biomass (DWB) of the studied fire chronosequence areas ( $>100 \mathrm{yrs}, \mathrm{n}=24 ; 56 \mathrm{yrs}, \mathrm{n}=22 ; 23 \mathrm{yrs}, \mathrm{n}=23 ; 1 \mathrm{yr}, \mathrm{n}=26$ ) (soil samples collected from depths of $0.05 \mathrm{~m}, 0.1 \mathrm{~m}, 0.3 \mathrm{~m}, 0.5 \mathrm{~m}$ and on top of the permafrost). Letters beside the mean values mark the significant differences $(p<0.05)$ between the analyzed fire age classes. Correlation coefficients $(\rho)$ are provided for studied forest fire age classes $(n=68)(y r=$ time since the forest fire), carbon dioxide $\left(\mathrm{CO}_{2}\right)$ and methane $\left(\mathrm{CH}_{4}\right)$. Statistical significance for measured variables $(p<0.05)$ is marked with *.

\begin{tabular}{|c|c|c|c|c|c|c|c|c|c|c|c|c|c|}
\hline $\begin{array}{l}\text { Forest } \\
\text { fire age } \\
\text { classes } \\
\text { (yr) }\end{array}$ & $\begin{array}{l}\text { Soil temp } \\
\text { at } 10 \mathrm{~cm} \\
\text { depth }\left({ }^{\circ} \mathrm{C}\right)\end{array}$ & $\begin{array}{l}\text { Soil } \\
\text { moisture } \\
(\%)\end{array}$ & $\begin{array}{l}\text { Soil pH } 5 \mathrm{~cm} / \\
\text { soil pH } \\
\text { deeper } \\
\text { than } 5 \mathrm{~cm}\end{array}$ & $\begin{array}{l}\text { Total } \\
\text { soil C } \\
\left(\mathrm{kg} \mathrm{m}^{-2}\right)\end{array}$ & $\begin{array}{l}\text { Total } \\
\text { soil } \mathrm{N} \\
\left(\mathrm{kg} \mathrm{m}^{-2}\right)\end{array}$ & $\begin{array}{l}\text { Depth } \\
\text { of active } \\
\text { layer } \\
\text { (m) }\end{array}$ & $\begin{array}{l}\text { Thickness } \\
\text { of soil } \\
\text { organic } \\
\text { layer (m) }\end{array}$ & $\begin{array}{l}\text { Ground } \\
\text { vegetation } \\
\text { coverage (\%) } \\
\text { (vascular } \\
\text { plants/moss + } \\
\text { lichens) }\end{array}$ & $\begin{array}{l}\text { Ground } \\
\text { vegetation } \\
\text { biomass }\left(\mathrm{kg} \mathrm{m}^{-2}\right) \\
\text { (vascular } \\
\text { plants/moss + } \\
\text { lichens) }\end{array}$ & $\begin{array}{l}\text { Alder } \\
\text { biomass } \\
\left(\mathrm{kg} \mathrm{m}^{-2}\right)\end{array}$ & $\begin{array}{l}\text { Birch } \\
\text { biomass } \\
\left(\mathrm{kg} \mathrm{m}^{-2}\right)\end{array}$ & $\begin{array}{l}\text { Larch } \\
\text { biomass } \\
\left(\mathrm{kg} \mathrm{m}^{-2}\right)\end{array}$ & $\begin{array}{l}\text { DWB (kg } \\
\left.\mathrm{m}^{-2}\right)\end{array}$ \\
\hline$>100$ yrs & $3.3^{\mathrm{A}}$ & $40.1^{A}$ & $5.5^{A} / 6.5^{A}$ & $10.5^{\mathrm{A}}$ & $0.49^{A}$ & $0.39^{A}$ & $0.123^{A}$ & $29,8^{A} / 95.3^{A}$ & $0.34^{A} / 0.55^{A}$ & $0.10^{A}$ & $0.02^{A}$ & $2.76^{A}$ & $1.12^{\mathrm{A}}$ \\
\hline 56 yrs & $5.8^{\mathrm{B}}$ & $30.4^{\mathrm{BC}}$ & $5.1^{A} / 6.1^{B}$ & $7.5^{\mathrm{A}}$ & $0.35^{\mathrm{B}}$ & $0.53^{\mathrm{AB}}$ & $0.103^{B}$ & $48.5^{B} / 74.5^{B}$ & $0.43^{\mathrm{B}} / 0.52^{\mathrm{A}}$ & $0.32^{\mathrm{B}}$ & $0.18^{\mathrm{B}}$ & $0.89^{\mathrm{B}}$ & $2.20^{\mathrm{B}}$ \\
\hline 23 yrs & $6.8^{B}$ & $36.1^{A B}$ & $5.7^{B} / 6.5^{A}$ & $7.6^{\mathrm{A}}$ & $0.39^{A B}$ & $0.77^{B}$ & $0.075^{C}$ & $65,9^{C} / 61.8^{B}$ & $0.30^{A} / 0.28^{B}$ & $0.08^{A}$ & $0.04^{A}$ & $0.13^{C}$ & $3.93^{C}$ \\
\hline $1 \mathrm{yr}$ & $14.9^{C}$ & $23.6^{C}$ & $5.8^{B} / 6.3^{A}$ & $3.0^{B}$ & $0.20^{C}$ & $1.31^{C}$ & $0.005^{\mathrm{D}}$ & $2.4^{D} / 2.9^{C}$ & $0.0^{C} / 0.0^{C}$ & $0.0^{C}$ & $0.0^{C}$ & $0.0^{\mathrm{D}}$ & $4.92^{D}$ \\
\hline$\rho(\mathrm{yr})$ & $-0.773 *$ & $0.383^{*}$ & $\begin{array}{l}-0.220 / \\
0.095\end{array}$ & $0.428 *$ & $0.416^{*}$ & $-0.712 *$ & $0.820^{*}$ & - & $0.343 * / 0.610 *$ & $0.372 *$ & 0.137 & $0.820 *$ & $-0.835^{*}$ \\
\hline$\rho\left(\mathrm{CO}_{2}\right)$ & $-0.569 *$ & 0.155 & $\begin{array}{l}-0.439 * / \\
-0.166\end{array}$ & 0.213 & 0.228 & $-0.412^{*}$ & $0.517^{*}$ & - & $0.391 * / 0.293^{*}$ & $0.166^{*}$ & $0.450 *$ & 0.107 & $-0.389 *$ \\
\hline$\rho\left(\mathrm{CH}_{4}\right)$ & -0.237 & -0.124 & $\begin{array}{l}0.102 / \\
-0.146\end{array}$ & -0.008 & -0.019 & 0.103 & 0.127 & - & $0.177 / 0.047$ & 0.046 & 0.085 & 0.116 & 0.097 \\
\hline
\end{tabular}



Table 3. Linear mixed effect models fitted against carbon dioxide $\left(\mathrm{CO}_{2}\right)$ flux and experimental factors. The fixed effects in the model were $\mathrm{CO}_{2}$ concentration; $\mathrm{SM}$ - soil moisture; $\mathrm{pH}_{0}-$ soil $\mathrm{pH}$ in top $5 \mathrm{~cm}$; $\mathrm{pH}_{\mathrm{M}}$ - soil $\mathrm{pH}$ from mineral part of soil; $\mathrm{TB}_{\text {Duschekia }}-$ tree biomass of alder $\left(\mathrm{kg} \mathrm{m}^{-2}\right)$; $\mathrm{TB}_{\text {Betula }}$ - tree biomass of birch $\left(\mathrm{kg} \mathrm{m}^{-2}\right) ; \mathrm{TB}_{\text {Larix }}$ - tree biomass of larch $\left(\mathrm{kg} \mathrm{m}^{-2}\right) ; \mathrm{B}_{\text {Grass }}$ - ground vegetation biomass of vascular plants $\left(\mathrm{kg} \mathrm{m}^{-2}\right)$; $\mathrm{B}_{\text {Moss }}$ - ground vegetation biomass of mosses and lichens $\left(\mathrm{kg} \mathrm{m}^{-2}\right) ; \mathrm{C} \%$ - soil carbon content $(\%) ; \mathrm{r}(\mathrm{YL})$ - random effect (collars in sample line); AIC - Akaike information criterion; $\mathrm{df}$ - degrees of freedom. The model in bold is the best fit model.

\begin{tabular}{|c|c|c|c|c|c|c|}
\hline Model & Mixed effect model equations & $r^{2}$ & $p$ & Intercept & AIC & $\mathrm{df}$ \\
\hline M 1 & $\mathrm{CO}_{2}=\mathrm{a}+\mathrm{bSM}+\mathrm{c} \mathrm{pH}_{0}+\mathrm{d} \mathrm{pH}_{\mathrm{M}}+\mathrm{e} \mathrm{TB}_{\text {Duschekia }}+\mathrm{fTB}_{\text {Betula }}+\mathrm{g} \mathrm{TB}_{\text {Larix }}+\mathrm{h} \mathrm{B}_{\text {Grass }}+\mathrm{i} \mathrm{B}_{\text {Moss }}+\mathrm{j} \mathrm{C}+\mathrm{r}(\mathrm{YL})$ & 0.63 & 0.03 & -2.7 & -133 & 12 \\
\hline M 2 & 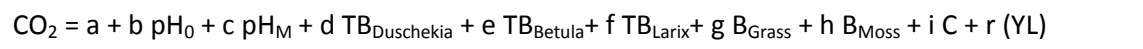 & 0.63 & 0.02 & -0.02 & -135 & 11 \\
\hline M 3 & $\mathrm{CO}_{2}=\mathrm{a}+\mathrm{b} \mathrm{pH}_{0}+\mathrm{c} \mathrm{pH}_{\mathrm{M}}+\mathrm{dT \textrm {B } _ { \text { Duschekia } }}+\mathrm{e} \mathrm{TB}_{\text {Betula }}+\mathrm{fB}_{\text {Grass }}+\mathrm{g} \mathrm{B}_{\text {Moss }}+\mathrm{h} \mathrm{C}+\mathrm{r}(\mathrm{YL})$ & 0.62 & 0.01 & -0.005 & -137 & 10 \\
\hline M 4 & $\mathrm{CO}_{2}=\mathrm{a}+\mathrm{b} \mathrm{pH}_{0}+\mathrm{cpH} \mathrm{MH}_{\mathrm{M}}+\mathrm{d} \mathrm{TB}_{\text {Duschekia }}+\mathrm{e} \mathrm{TB}_{\text {Betula }}+\mathrm{fB}_{\text {Grass }}+\mathrm{g} \mathrm{B}_{\text {Moss }}+\mathrm{r}(\mathrm{YL})$ & 0.62 & 0.007 & -0.006 & -139 & 9 \\
\hline M 5 & $\mathrm{CO}_{2}=\mathrm{a}+\mathrm{b} \mathrm{pH}_{0}+\mathrm{c} \mathrm{pH}_{\mathrm{M}}+\mathrm{dT} \mathrm{TB}_{\text {Duschekia }}+\mathrm{eTB} \mathrm{BB}_{\text {Betula }}+\mathrm{f} \mathrm{B}_{\text {Grass }}+\mathrm{r}(\mathrm{YL})$ & 0.62 & 0.004 & -0.02 & -140 & 8 \\
\hline M 6 & $\mathrm{CO}_{2}=\mathrm{a}+\mathrm{b} \mathrm{pH}_{0}+\mathrm{c} \mathrm{TB}_{\text {Duschekia }}+\mathrm{d} \mathrm{TB}_{\text {Betula }}+\mathrm{e} \mathrm{B}_{\mathrm{Grass}}+\mathrm{r}(\mathrm{YL})$ & 0.62 & 0.004 & 0.29 & -140 & 7 \\
\hline
\end{tabular}


Table 4. Linear mixed effect models fitted against methane $\left(\mathrm{CH}_{4}\right)$ flux and experimental factors. The fixed effects in the model were $\mathrm{CH}_{4}$ concentration; $\mathrm{SM}$ - soil moisture; $\mathrm{pH}_{0}-$ soil $\mathrm{pH}$ in top $5 \mathrm{~cm}$; $\mathrm{pH}_{\mathrm{M}}-$ soil $\mathrm{pH}$ from mineral part of soil; $\mathrm{TB}_{\text {Duschekia }}$ - tree biomass of alder $\left(\mathrm{kg} \mathrm{m}^{-2}\right)$; $\mathrm{TB}_{\text {Betula }}$ - tree biomass of birch $\left(\mathrm{kg} \mathrm{m}^{-2}\right) ; \mathrm{TB}_{\text {Larix }}$ - tree biomass of larch $\left(\mathrm{kg} \mathrm{m}^{-2}\right) ; \mathrm{B}_{\text {Grass }}$ - ground vegetation biomass of vascular plants $\left(\mathrm{kg} \mathrm{m}^{-2}\right)$; $B_{\text {Moss }}$ - ground vegetation biomass of mosses $\left(\mathrm{kg} \mathrm{m}^{-2}\right)$; $\mathrm{C} \%$ - soil carbon content (\%); $r(\mathrm{YL})$ - random effect (collars in sample line); AIC - Akaike information criterion; $\mathrm{df}$ - degrees of freedom. The model in bold is the best fit model.

\begin{tabular}{|c|c|c|c|c|c|c|}
\hline Model & Mixed effect model equations & $r^{2}$ & $p$ & Intercept & AIC & df \\
\hline M 1 & 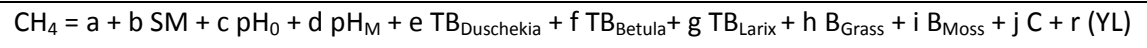 & 0.36 & 0.65 & $4.90 \mathrm{E}-05$ & -1183 & 12 \\
\hline M 2 & $\mathrm{CH}_{4}=\mathrm{a}+\mathrm{bSM}+\mathrm{c} p \mathrm{H}_{0}+\mathrm{dpH} \mathrm{H}_{\mathrm{M}}+\mathrm{e} \mathrm{TB}_{\text {Duschekia }}+f \mathrm{~TB}_{\text {Betula }}+\mathrm{g} \mathrm{TB}_{\text {Larix }}+\mathrm{h} \mathrm{B}_{\text {Grass }}+\mathrm{i} \mathrm{C}+\mathrm{r}(\mathrm{YL})$ & 0.35 & 0.56 & 4.70E-05 & -1185 & 11 \\
\hline M 3 & $\mathrm{CH}_{4}=\mathrm{a}+\mathrm{bSM}+\mathrm{c} \mathrm{pH}_{0}+\mathrm{dpH} \mathrm{H}_{\mathrm{M}}+\mathrm{e} \mathrm{TB}_{\text {Duschekia }}+\mathrm{fTB}_{\text {Larix }}+\mathrm{g} \mathrm{B}_{\mathrm{Grass}}+\mathrm{hC}+\mathrm{r}(\mathrm{YL})$ & 0.34 & 0.47 & 4.60E-05 & -1187 & 10 \\
\hline M 4 & $\mathrm{CH}_{4}=\mathrm{a}+\mathrm{bSM}+\mathrm{cpH} \mathrm{H}_{0}+\mathrm{dp} \mathrm{H}_{\mathrm{M}}+\mathrm{e} \mathrm{TB}_{\text {Larix }}+f \mathrm{~B}_{\text {Grass }}+\mathrm{g} \mathrm{C}+\mathrm{r}(\mathrm{YL})$ & 0.30 & 0.38 & $2.80 \mathrm{E}-05$ & -1188 & 9 \\
\hline M 5 & $\mathrm{CH}_{4}=\mathrm{a}+\mathrm{bpH} \mathrm{pH}_{0}+\mathrm{cpH} \mathrm{H}_{\mathrm{M}}+\mathrm{dT \textrm {B } _ { \text { Larix } }}+\mathrm{e} \mathrm{B}_{\mathrm{Grass}}+\mathrm{fC}+\mathrm{r}(\mathrm{YL})$ & 0.29 & 0.30 & $3.10 \mathrm{E}-05$ & -1190 & 8 \\
\hline M 6 & $\mathrm{CH}_{4}=\mathrm{a}+\mathrm{b} p \mathrm{pH}_{\mathrm{M}}+\mathrm{c} \mathrm{TB}_{\text {Larix }}+\mathrm{d}$ Bmodel $_{\text {Grass }}+\mathrm{e} \mathrm{C}+\mathrm{r}(\mathrm{YL})$ & 0.31 & 0.26 & 4.40E-05 & -1191 & 7 \\
\hline M 7 & $\mathrm{CH}_{4}=\mathrm{a}+\mathrm{b} p \mathrm{H}_{\mathrm{M}}+\mathrm{c} \mathrm{B}_{\text {Grass }}+\mathrm{d} \mathrm{C}+\mathrm{r}(\mathrm{YL})$ & 0.26 & 0.25 & $3.70 \mathrm{E}-05$ & -1192 & 6 \\
\hline M 8 & $\mathrm{CH}_{4}=\mathrm{a}+\mathrm{b} \mathrm{pH}_{\mathrm{M}}+\mathrm{c} \mathrm{B} \mathrm{B}_{\text {Grass }}+\mathrm{r}(\mathrm{YL})$ & 0.23 & 0.22 & 3.30E-05 & -1193 & 5 \\
\hline
\end{tabular}

